\title{
Polycyclic alpine orogeny in the Rhodope metamorphic complex: the record in migmatites from the Nestos shear zone (N. Greece)
}

\author{
Pierre Gautier ${ }^{1, *}$, Valérie Bosse ${ }^{2}$, Zlatka Cherneva ${ }^{3}$, Amélie Didier $^{2}$, Ianko Gerdjikov ${ }^{3}$ \\ and Massimo Tiepolo ${ }^{4}$ \\ ${ }^{1}$ Université Rennes 1, CNRS, Géosciences Rennes UMR6118, OSUR, 35042 Rennes cedex, France \\ ${ }^{2}$ Université Clermont-Auvergne, CNRS, IRD, OPGC, Laboratoire Magmas et Volcans, 63000 Clermont-Ferrand, France \\ 3 Sofia University "St Kliment Ohridski",15 Tzar Osvoboditel, 1504 Sofia, Bulgaria \\ ${ }^{4}$ University of Milano, Earth Sciences Department, Via Mangiagalli 34, 20133 Milano, Italy
}

\begin{abstract}
The Rhodope Metamorphic Complex (RMC) is a high-grade crystalline massif located at the northern margin of the Aegean region. Numerous scenarios have been proposed for the evolution of the RMC during Alpine times. A debated issue is whether there has been a single protracted orogenic cycle since around the mid-Mesozoic or whether Alpine orogeny involved distinct episodes of subduction and crustal accretion. We describe a key outcrop located on the Nestos Shear Zone (NSZ), a major NNE-dipping top-toSW shear zone characterized by an inverted metamorphic sequence. Structural and petrological data document the existence of two anatectic events. The first event, best preserved in decametric structural lenses, is pre-kinematic with respect to top-to-SW shearing and involved high-temperature "dry" melting. Zircon and monazite LA-ICPMS U-Th-Pb data indicate that this event occurred at $\sim 140 \mathrm{Ma}$. The second event is syn-kinematic with respect to top-to-SW shearing and involved lower-temperature water-assisted melting. Zircon and rutile LA-ICPMS U-Pb data indicate that this second event occurred at $\sim 40 \mathrm{Ma}$. During ongoing top-to-SW shearing and as late as $\sim 36 \mathrm{Ma}$, the rocks from the outcrop were at higher temperatures than the peak temperatures experienced by lower levels of the NSZ. This confirms the existence of the inverted metamorphic sequence and demonstrates that the NSZ was a major thrust at 36-40 Ma. The $\sim 100 \mathrm{Myr}$ time laps between the two anatectic events encompasses the period from $\sim 115$ to $\sim 70 \mathrm{Ma}$ characterized by a gap in the geochronological record on the scale of the RMC (the Eastern Rhodope excluded). This $\sim 45 \mathrm{Myr}$ gap likely reflects a period of tectonic quiescence between the mid-Mesozoic orogen and the Cenozoic one, attesting for polycyclic Alpine orogeny in the RMC. Unlike assumed in several geodynamic scenarios, the Alpine evolution of the RMC did not consist of a single orogenic cycle of Mesozoic age followed by Cenozoic crustal-scale extension triggered by mantle delamination. Polycyclic orogeny has resulted in a two-loop P-T-t path for the hangingwall unit of the NSZ. The Cenozoic P-T paths of this unit and the footwall unit merged while both units were being exhumed, a feature attributed to synthrusting extensional spreading of the main mass of the hangingwall unit above the NSZ.
\end{abstract}

Keywords: Aegean / syn-deformation migmatization / U-Pb dating / LA-ICPMS / inverted metamorphism / synmetamorphic thrusting

Résumé - Orogenèse alpine polycyclique dans le complexe métamorphique du Rhodope: enregistrement dans les migmatites de la zone de cisaillement du Nestos (Grèce). Le Rhodope est un complexe métamorphique de haut grade situé à la frange Nord de la région égéenne. De nombreux scénarios ont été proposés pour son évolution durant la période alpine. Une question débattue est de déterminer s'il n'y a eu qu'un seul cycle orogénique de longue durée depuis le milieu du Mésozoïque ou bien si l'orogenèse alpine a impliqué des épisodes distincts de subduction-accrétion crustale. Nous décrivons un affleurement-clé situé sur la "Nestos Shear Zone» (NSZ), une zone de cisaillement majeure inclinée au NNE et à vergence $\mathrm{SW}$, caractérisée par une séquence métamorphique inverse. Les données structurales et pétrologiques documentent l'existence de deux événements anatectiques. Le premier, mieux préservé au sein de lentilles structurales décamétriques, est pré-cinématique vis-à-vis du cisaillement vers le $\mathrm{SW}$ et

*Corresponding author: pierre.gautier@univ-rennes1.fr 
implique une fusion anhydre, de haute température. Les données U-Th-Pb obtenues par LA-ICPMS sur zircon et monazite indiquent que cet événement s'est produit vers $140 \mathrm{Ma}$. Le second événement est syncinématique vis-à-vis du cisaillement vers le SW et implique une fusion hydratée, de plus basse température. Les données U-Pb obtenues par LA-ICPMS sur zircon et rutile indiquent que ce second événement s'est produit vers $40 \mathrm{Ma}$. Durant le maintien du cisaillement vers le SW et jusqu'à $36 \mathrm{Ma}$, les roches de l'affleurement étaient à des températures supérieures aux températures maximales subies par les niveaux inférieurs de la NSZ. Ceci confirme l'existence de la séquence métamorphique inverse et démontre que la NSZ était un chevauchement majeur à 36-40 Ma. Le laps de temps de $100 \mathrm{Ma}$ entre les deux événements anatectiques englobe la période comprise entre $\sim 115$ et $\sim 70 \mathrm{Ma}$, caractérisée par une lacune dans l'enregistrement géochronologique à l'échelle du Rhodope (le Rhodope oriental exclu). Cette lacune de $\sim 45$ Ma reflète probablement une période tectoniquement calme entre l'orogène du milieu du Mésozoïque et celui du Cénozoïque, attestant du caractère polycyclique de l'orogenèse alpine dans le Rhodope. Contrairement à l'hypothèse de certains scénarios, l'évolution du Rhodope ne s'est pas limitée à un seul cycle orogénique mésozoïque suivi au Cénozoïque par un épisode d'extension crustale déclenché par délamination du manteau. Du fait du caractère polycyclique de l'orogenèse, l'unité supérieure de la NSZ a suivi un chemin pression-température-temps comprenant deux boucles. Les segments pression-température cénozoïques de cette unité et de l'unité inférieure se sont rejoints alors que les deux unités étaient en cours d'exhumation. Ce fait est attribuable à l'extension par étalement gravitaire de la masse principale de l'unité supérieure, au-dessus de la NSZ, durant le mouvement chevauchant.

Mots clés : Egée / migmatisation syn-déformation / datation U-Pb / LA-ICPMS / métamorphisme inverse / chevauchement synmétamorphique

\section{Introduction}

Crystalline complexes occasionally include rocks having experienced polycyclic metamorphism due to their involvement in several successive orogens and/or other geodynamic settings (e.g., rifting). The evidence for a polycyclic evolution is not always straightforward as polycyclism needs to be distinguished from the successive stages of a continuous pressure-temperature (P-T) evolution during a single orogenic cycle. Structural information can help, but the possible identification of several phases of deformation may only reflect the complex tectonic evolution of a single orogen. The best evidence may come from geochronological data when the obtained range of ages exceeds by far the maximum duration of an orogenic cycle, insofar as the latter can be fixed. The argument becomes stronger if the geochronological dataset shows evidence for two groups of ages separated by a long time laps, suggesting an intermediate period of tectonic quiescence. Then, however, assessing the geological meaning of each group of ages may prove to be difficult. Ideally, for a robust output of the geochronological work, one seeks to establish correlations between the ages and the mineralogical assemblages, microstructures, and macroscopic features of the dated rocks. Conversely, an erroneous attribution of some ages to some structures and/or metamorphic assemblages can lead to a wrong tectonic scenario. This is especially true in the case of polycyclism, as, for instance, specific conditions of metamorphism (e.g., eclogitization, migmatization) related to an old orogen may be attributed to the younger orogen. Hence, in crystalline complexes where geochronological data cover a wide range of ages, special attention must be paid to the relations between structures, metamorphism, and the dated minerals.

This study is about the Rhodope Metamorphic Complex (RMC), a high-grade crystalline complex straddling the border between Greece and Bulgaria (Fig. 1). Since the late 1990s, numerous scenarios have been proposed for the tectonic evolution of the RMC during Alpine times. A primary difference between these scenarios is whether there has been a single protracted orogenic cycle since around the midMesozoic (Ricou et al., 1998; Barr et al., 1999; Papanikolaou and Kranis, 2004; Turpaud and Reischmann, 2010; Krenn et al., 2010; Burg, 2011; Kydonakis et al., 2016) or whether Alpine orogeny involved distinct episodes of subduction and crustal accretion (Liati, 2005; Mposkos et al., 2010; Liati et al., 2011, 2016; Nagel et al., 2011; Kirchenbaur et al., 2012; Froitzheim et al., 2014; Wawrzenitz et al., 2015). The difference between the two views mainly stems from different interpretations of the available geochronological data (e.g., Burg, 2011; Liati et al., 2011).

Here we present a detailed analysis of a key outcrop in the Greek Rhodope, which enables us to discuss and decide between the two options. The studied outcrop belongs to the Nestos Shear Zone (NSZ) (Fig. 1), a major ductile shear zone with top-to-SW kinematics that has received much attention since the 1990s. Contrasting opinions exist as for the origin of top-to-SW shearing along the NSZ, which could reflect either thrusting (e.g., Kilias and Mountrakis, 1990; Barr et al., 1999; Krohe and Mposkos, 2002) or extensional shearing (Nagel et al., 2011). Determining the origin and age of shearing along the NSZ is important considering the apparent conflict that exists between scenarios favoring crustal-scale extension across the RMC since 40 Ma or more (e.g., Kilias et al., 1999; Brun and Sokoutis, 2007; Jolivet and Brun, 2010; Burg, 2011; van Hinsbergen and Schmid, 2012) and studies suggesting ongoing thrusting along the NSZ as late as $37 \mathrm{Ma}$ (Dinter, 1998; Krohe and Mposkos, 2002) or 33 Ma (Bosse et al., 2009; Gautier et al., 2010) and/or eclogite facies metamorphism in the RMC as late as 42-45 Ma (Liati and Gebauer, 1999; Liati et al., 2011; Kirchenbaur et al., 2012). A full analysis of the NSZ is beyond the scope of this paper, nevertheless the results obtained in this study provide critical information for determining the significance of this major shear zone and the tectonic evolution of the RMC. 


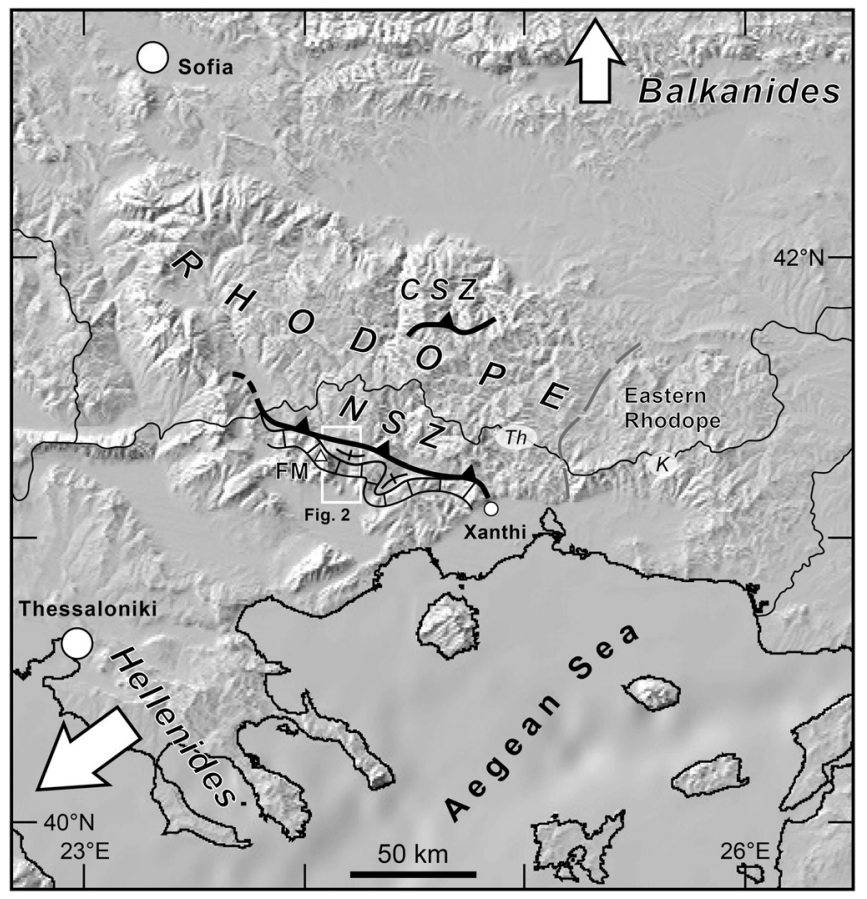

Fig. 1. Topographic map of the northern Aegean domain showing the location of the Rhodope Metamorphic Complex and, within it, the Nestos Shear Zone (NSZ) and the Chepelare Shear Zone (CSZ). The two arrows indicate the vergence of Alpine thrusting in the Balkanides (to the north) and the Hellenides (to the southwest). FM: Falakron mountain; Th: Thermes area; K: Kimi area.

\section{The Mesozoic-Cenozoic geochronological record of the Rhodope: a critical review in the light of current tectonic interpretations}

The RMC occupies a central position in the Alpine orogen of the eastern Mediterranean, between the southwest-vergent Hellenides and the north-vergent Balkanides (Fig. 1). It consists of medium- to high-grade metamorphic rocks and abundant granitoid intrusions, partly covered by sedimentary and volcanic rocks. A great number of geochronological data have been published on the RMC, leading to the now largely accepted view that metamorphism and magmatism essentially result from Mesozoic to Cenozoic events related to the Alpine orogeny and post-orogenic "Aegean" extension. Beyond this agreement, however, contrasting interpretations exist.

One issue concerns the spatial distribution of coherent tectono-metamorphic units on the scale of the RMC. Various structural sketches have been proposed (e.g., Burg et al., 1996; Ivanov et al., 2000; Krohe and Mposkos, 2002; Turpaud, 2006; Jahn-Awe et al., 2010; Burg, 2011). Although no consensus exists, there is a general agreement that the central part of the RMC involves at least two major north-dipping shear zones, the NSZ and the Chepelare Shear Zone (CSZ) (Fig. 1). The two shear zones were initially regarded as distinct, synthetic thrust zones (Ricou et al., 1998). Because they display roughly the same petro-geochronological record (e.g., Bosse et al., 2009; Didier et al., 2014), the NSZ and CSZ have been reinterpreted as two occurrences of the same shear zone (Turpaud and
Reischmann, 2010; Nagel et al., 2011; Burg, 2011). With respect to the NSZ, Papanikolaou and Panagopoulos (1981) initially defined a lower unit and an upper unit, later named the Pangaeon Unit (PU) and Sidironero Unit (SU). These names are the most popular in the literature and will also be used in this work. The PU is equivalent to the "Thracia Terrane" of Turpaud and Reischmann (2010), the "Lower Terrane" of Burg (2011), and the "Lower Allochthon" of Nagel et al. (2011). The $\mathrm{SU}$ is equivalent to the "Rhodope Terrane" of Turpaud and Reischmann (2010) and the "Middle Allochthon" of Nagel et al. (2011). A large part of the SU consists of migmatites and granitic plutons derived from the anatectic melts. The main part of the PU shows rocks metamorphosed in upper greenschist to lower amphibolite facies conditions. In the case of the CSZ, the footwall unit, which probably correlates with the PU (e.g., Turpaud and Reischmann, 2010), mostly consists of migmatized orthogneisses.

As outlined above, another debated issue is whether Alpine orogeny consisted of a single protracted cycle (e.g., Burg, 2011) or involved distinct episodes of subduction and crustal accretion (e.g., Liati et al., 2011; Froitzheim et al., 2014). With regard to this question, two aspects of the Mesozoic-Cenozoic geochronological record deserve special attention.

\subsection{Continuous versus discontinuous metamorphic evolution and geochronological record}

Since about a decade, the concept of polycyclic Alpine orogeny in the RMC has emerged on the basis of two main arguments.

A first argument is based on the interpretation of some U$\mathrm{Pb}$ SHRIMP zircon ages that suggest the existence of four distinct high-pressure (HP) metamorphic events in the RMC, with ages of $\sim 150, \sim 73, \sim 51$, and $\sim 42 \mathrm{Ma}$ (Liati and Gebauer, 1999; Liati, 2005; Liati et al., 2011, 2016). The earliest event, which most authors associate with the presence of ultrahighpressure (UHP) metamorphic relics in some rocks (e.g., Mposkos and Kostopoulos, 2001), is much debated and could be as old as $200 \mathrm{Ma}$ (e.g., Nagel et al., 2011; Petrik et al., 2016). According to Liati (2005) and Liati et al. (2011), their $\mathrm{U}-\mathrm{Pb}$ data document the existence of several episodes of eclogitization and subduction, consistent with a model of punctuated orogeny involving the accretion of distinct microcontinents. Some localities are reported to have recorded at least two HP events, suggesting renewed subduction. In the Eastern Rhodope, some rocks of the Kimi area (Fig. 1) may have recorded both the $\geq 150 \mathrm{Ma}$ UHP and the $\sim 73 \mathrm{Ma} \mathrm{HP}$ events (Liati et al., 2011, 2016). Lu-Hf garnet-whole rock ages of $\sim 43-45 \mathrm{Ma}$ from retrogressed eclogites of the Bulgarian Central Rhodope have also been interpreted as dating HP conditions and the contemporaneous existence of a subduction setting in the RMC (Kirchenbaur et al., 2012). Based on their results, Kirchenbaur et al. (2012) suggested that the two HP events at $\sim 42$ and $\sim 51 \mathrm{Ma}$ inferred by Liati and Gebauer (1999) and Liati (2005) probably reflect the same subduction event. Several authors have expressed doubts on the interpretation of the above ages as reflecting HP conditions, at least for those implying a subduction setting in the RMC as late as 42-51 Ma (Barr et al., 1999; Krohe and Mposkos, 2002; Turpaud and Reischmann, 2010; Burg, 2011; Moulas et al., 
2013; Kydonakis et al., 2016). Although not the main topic of this paper, we will come back to this issue in the discussion (see Sect. 6.3) because the outcrop studied here is the same where Liati (2005) identified the HP event at $51 \mathrm{Ma}$. All the rocks yielding the above set of HP ages belong to lower levels of the SU or to units with a higher position in the metamorphic pile (Liati, 2005; Liati et al., 2011; Nagel et al., 2011; Kirchenbaur et al., 2012). In contrast, although Turpaud and Reischmann (2010) and Wawrzenitz et al. (2015) have questioned this point, it seems that none of these rocks belong to the PU.

The second argument stems from the observation that the RMC contains rocks, or rock assemblages, that display two sets of "Alpine" ages related to high-temperature metamorphic conditions (U-Pb zircon and $\mathrm{U}-\mathrm{Th}-\mathrm{Pb}$ monazite ages), the two sets being separated by a time laps of at least $60 \mathrm{Myr}$, between $\geq 115$ and $\leq 55 \mathrm{Ma}$ (Liati, 2005; Bosse et al., 2009; Didier et al., 2014; Wawrzenitz et al., 2015). More generally, except in the Eastern Rhodope (Fig. 1), the RMC is characterized by an almost complete lack of radiometric ages in the time interval between $\sim 115$ and $\sim 70 \mathrm{Ma}$. Ages around $70 \mathrm{Ma}$ are found along the northern margin of the RMC where several intrusions were emplaced at $\sim 67-72 \mathrm{Ma}$, representing a southern extension of the adjacent Srednogorie magmatic arc (von Quadt and Peytcheva, 2005; Gallhofer et al., 2015). As suggested in Section 1, the existence of a large time gap ( $\geq$ $45 \mathrm{Myr}$ ) in the geochronological record seems to support the hypothesis of a polycyclic orogenic evolution for the largest part of the RMC. Using the age data of Liati (2005) and Bosse et al. (2009), Mposkos et al. (2010) have followed this line of reasoning and additionally argued that some of the garnetkyanite metapelites found along the NSZ keep the record of a polycyclic P-T evolution. A first P-T loop, of presumed midMesozoic age, reached UHP conditions followed by granulite facies retrogression while a second P-T loop, of presumed a mid-Cenozoic age, would have reached P-T conditions of $\sim 12 \mathrm{kbar}$ and $\sim 650^{\circ} \mathrm{C}$ (Mposkos et al., 2010). In that study, however, the second prograde path, which is crucial for documenting renewed thrusting, is poorly substantiated. Based on new age data, Wawrzenitz et al. (2015) have also suggested a two-loop P-T path for a garnet-kyanite metapelite from Thermes (Fig. 1), but the authors acknowledge that only segments of this complex P-T evolution can be documented, the second prograde path remaining conjectural.

Regardless, the large time gap in the geochronological record of the RMC (the Eastern Rhodope excluded), between $\sim 115$ and $\sim 70 \mathrm{Ma}$, seems difficult to reconcile with the hypothesis of a single protracted orogeny (e.g., Ricou et al., 1998; Burg, 2011). In his review of geochronological data on the RMC, Burg (2011) has reported two U-Pb zircon ages of $83 \mathrm{Ma}$ and "around $77 \mathrm{Ma}$ " from the Central Rhodope. Such intermediate ages could be viewed as supporting the picture of a protracted high-temperature metamorphic evolution. The age of 83 Ma comes from a sample on the NSZ, north of Xanthi (Fig. 1), in which most analyses on the metamorphic rims of zircon grains are between $\sim 145$ and $\sim 155 \mathrm{Ma}$, yielding a mean age of $149 \pm 2 \mathrm{Ma}$ (Liati, 2005). As discussed by Liati (2005), the age of $83 \mathrm{Ma}$ is the youngest of a small set of analyses that reflect variable $\mathrm{Pb}$-loss during a disturbing event, the maximum possible age of which is $83 \mathrm{Ma}$. At the same locality, U-Pb data provide evidence for high-temperature metamorphism at $\sim 40-53 \mathrm{Ma}$ (Liati, 2005; Bosse et al., 2009). Most probably, thus, the age of $83 \mathrm{Ma}$ is geologically meaningless. The same holds true for the age of "around $77 \mathrm{Ma}$ " (in fact, three ages scattered between 77 and $97 \mathrm{Ma}$, in addition to ages of $\sim 150 \mathrm{Ma}$ and more), which was obtained on a pegmatite vein from the $\mathrm{CSZ}$ for which $\mathrm{Th}-\mathrm{Pb}$ monazite data document an emplacement at $\sim 36 \mathrm{Ma}$ (Bosse et al., 2009). In two recent $\mathrm{U}-\mathrm{Th}-\mathrm{Pb}$ monazite dating studies of the garnetkyanite metapelites from the NSZ and CSZ (Didier et al., 2014) and at Thermes (Wawrzenitz et al., 2015), two peaks of ages have been obtained, at $\sim 130-150 \mathrm{Ma}$ and $\sim 36-55 \mathrm{Ma}$, as well as a series of intermediate ages, some of which fall in the 70-115 Ma time range. As discussed by Didier et al. (2014) and Wawrzenitz et al. (2015) on the basis of textural and geochemical arguments, these intermediate ages should be understood as geologically meaningless.

The picture of a large gap in the geochronological record of the Central Rhodope is challenged by a recent study by Collings et al. (2016). Like the studies of Didier et al. (2014) and Petrik et al. (2016), this work aimed at dating the garnetkyanite gneisses exposed along the CSZ. Collings et al. (2016) have obtained five Sm-Nd garnet-whole rock ages ranging between $\sim 70$ and $\sim 90 \mathrm{Ma}$ and argued that these ages date the UHP metamorphic event testified by the presence of microdiamond inclusions in garnet. Petrik et al. (2016) have already contested this interpretation and argued, instead, that the UHP event occurred at $\sim 200 \mathrm{Ma}$. The meaning of the $\sim 70-90 \mathrm{Ma}$ Sm-Nd ages is questionable because U-Th- $\mathrm{Pb}$ monazite dating of the same lithology in the same area has yielded the two age peaks quoted above, at $\sim 130-150 \mathrm{Ma}$ and $\sim 36 \mathrm{Ma}$ (Didier et al., 2014). Noteworthily, sample 2-111 of Collings et al. (2016) and sample P04-630 of Didier et al. (2014) come from the same small outcrop. Collings et al. (2016) argue that their data establish the timing of garnet growth because one of the Sm-Nd isochron is built on distinct fragments of a single large garnet that has kept a chemical (Mn) record of growth zoning. However, judging from the figure 4 of Collings et al. (2016), the evidence for growth zoning is poor; moreover, the isochron is based on three garnet fragments located along the rim of the grain in a domain of homogeneous Mn composition. Mn zoning is best expressed at the core of the grain but the corresponding garnet fragment does not fit the isochron and yields a younger apparent age of $\sim 48 \mathrm{Ma}$. The rock containing this garnet is from the same outcrop where Petrik et al. (2016) collected their sample. Petrik et al. (2016) describe the large garnets of their sample as chemically nearly homogeneous and variably resorbed along the rims and some fractures (see their figure 5), a feature also visible in the figure 4 of Collings et al. (2016). Altogether, these facts cast serious doubt on the Sm-Nd ages of Collings et al. (2016) as having a geological meaning. A histogram of "published metamorphic ages from across the RMC" is given in Collings et al. (2016, their figure 8 ), in which the $\sim 70-90 \mathrm{Ma}$ period coincides with a prominent peak of ages. This peak is built on:

- the five Sm-Nd ages of questionable meaning;

- five ages from the Eastern Rhodope;

- two ages from the Central Rhodope, which are those also reported in the synthesis of Burg (2011) and already commented above. 
Therefore, we maintain the view that, to date, with the exception of the Eastern Rhodope, the largest part of the RMC is characterized by a lack of reliable radiometric ages in the time interval between $\sim 115$ and $\sim 70 \mathrm{Ma}$.

From the metamorphic units of the Chalkidiki region, east of Thessaloniki (Fig. 1), Kydonakis et al. (2016) have recently reported ${ }^{40} \mathrm{Ar} /{ }^{39} \mathrm{Ar}$ white mica ages between $\sim 95$ and $\sim 125 \mathrm{Ma}$ and, from a garnet-kyanite micaschist, one $\mathrm{U}-\mathrm{Th}-\mathrm{Pb}$ monazite age of $\sim 130 \mathrm{Ma}$. Combining these ages with petrological and structural data, Kydonakis et al. (2016) infer that the Chalkidiki region and the RMC shared a common tectonometamorphic evolution during at least part of the Mesozoic, as long suspected (e.g., Ricou et al., 1998; Kilias et al., 1999), and that thrusting in Chalkidiki ceased before $\sim 120-125 \mathrm{Ma}$. The latter point is consistent with an interpretation of the $\sim 115$ to $\sim 70 \mathrm{Ma}$ "geochronological gap" of the RMC as reflecting a period of tectonic quiescence. In addition, Kydonakis et al. (2016) suggest that the high-temperature conditions that prevailed in the RMC during the Cenozoic have erased its earlier medium-temperature geochronological record (Cretaceous ${ }^{40} \mathrm{Ar}{ }^{39} \mathrm{Ar}$ ages), which is now preserved in Chalkidiki only. A pre-Cenozoic ${ }^{40} \mathrm{Ar} /{ }^{39} \mathrm{Ar}$ record may indeed have been erased in the tectonic units of the RMC that display U-Th- $\mathrm{Pb}$ evidence of the mid-Mesozoic metamorphic loop (e.g., the SU, see Sect. 3). In contrast, erasure remains conjectural for the units devoid of this evidence. Of them, the PU, which is situated at a lower level of the structural pile, might have been engaged in the orogen only lately, during the Cenozoic (Argyriadis and Fourquin, 1987; Dinter, 1998; Krohe and Mposkos, 2002; Jahn-Awe et al., 2010; Nagel et al., 2011; Froitzheim et al., 2014). Thus, the key issue is the tectonic setting under which the high-temperature conditions were produced during the Cenozoic, and whether renewed thrusting occurred in the RMC at that time.

\subsection{What happened during the Cenozoic?}

There is no consensus on the tectonic evolution of the RMC during the Cenozoic. For some authors, based on the interpretation of geochronological data obtained on retrogressed eclogites, a subduction setting existed as late as $\sim 42-$ $51 \mathrm{Ma}$ (Liati and Gebauer, 1999; Liati, 2005; Liati et al., 2011; Nagel et al., 2011; Kirchenbaur et al., 2012; Froitzheim et al., 2014) (see Sect. 2.1). For other authors, although not necessarily agreeing with the interpretation of the above ages as reflecting HP conditions, synmetamorphic thrusting (i.e., thrusting giving rise to ductile fabrics formed under metamorphic conditions) remained active until $37 \mathrm{Ma}$ (Dinter, 1998; Krohe and Mposkos, 2002) or 33-35 Ma (Bosse et al., 2009; Gerdjikov et al., 2010). Noteworthily, most studies suggesting persistent synmetamorphic thrusting in the RMC during the Middle-Late Eocene rely on arguments and geochronological data attached to the NSZ (see below). For a third group of authors, no significant thrusting event occurred in the RMC during the Cenozoic and, instead, crustal-scale "core complex"-type extension developed during much of the period, starting at $\sim 40 \mathrm{Ma}$ (Brun and Sokoutis, 2007; Burg, 2011) or earlier (45-50 Ma; Kilias et al., 1999; Jolivet and Brun, 2010; van Hinsbergen and Schmid, 2012). Cenozoic widespread magmatism and high-temperature metamorphism, attested by numerous geochronological data throughout the $\mathrm{RMC}$, is now interpreted as resulting from a process of mantle delamination initiated at $40 \mathrm{Ma}$ (Yanev et al., 1998; Burg, 2011) or $\sim 50-56 \mathrm{Ma}$ (Jolivet and Brun, 2010; Marchev et al., 2013). Following Burg (2011), mantle delamination may have triggered crustal-scale "core complex"-type extension and, importantly, may explain the development of a major tectonometamorphic event during the Cenozoic, long after the midMesozoic orogeny, without the requirement of a new orogenic period (see also Kydonakis et al., 2016). Alternatively, mantle delamination may have occurred in the immediate aftermath of an early Cenozoic orogeny (Nagel et al., 2011; Froitzheim et al., 2014).

In view of these contrasting opinions, it is useful to consider the different interpretations given for the NSZ. The main argument for assigning the top-to-SW shear fabric of the NSZ to thrusting is the presence of an inverted metamorphic sequence across the shear zone (e.g., Jordan, 1969; Kronberg and Raith, 1977; Zachos and Dimadis, 1983; Kilias and Mountrakis, 1990; Kotopouli et al., 1991; Krohe and Mposkos, 2002). However, this inverted metamorphic sequence is difficult to interpret, in particular because its relationship with ductile fabrics is not always established or is contradictory from one study to the next. For instance, migmatization at higher levels of the NSZ, within the SU, is considered either as pre-kinematic (Kilias and Mountrakis, 1990; Turpaud and Reischmann, 2010) or syn- to latekinematic (Kronberg and Raith, 1977; Zachos and Dimadis, 1983; Barr et al., 1999) with respect to the main shear fabric. As for the age of the shear zone, the inference that is was active during the Eocene (Barr et al., 1999) and as late as $37 \mathrm{Ma}$ (Dinter, 1998; Krohe and Mposkos, 2002) relies mainly on a set of K-Ar hornblende ages between 37 and $47 \mathrm{Ma}$ (Liati, 1986). Many authors implicitly consider that these K-Ar data yield only a minimum possible age of shearing, so that the NSZ can be accepted as a major SW-vergent thrust of much older age (Mesozoic or Mesozoic-Paleocene; Ricou et al., 1998; Papanikolaou and Kranis, 2004; Krenn et al., 2010; Burg, 2011; Schenker et al., 2014; Kydonakis et al., 2016; Brun et al., 2016). With regard to the age and tectonic significance of the NSZ, three studies should be considered more closely.

At intermediate levels of the NSZ north of Xanthi, within the SU, Bosse et al. (2009) have described pegmatite veins that represent melts extracted from the host migmatitic gneisses. The veins display moderate to locally strong deformation with a schistosity paralleling the mylonitic foliation of the shear zone. They have yielded one $\mathrm{U}-\mathrm{Pb}$ zircon age of $\sim 48 \mathrm{Ma}$ and $\mathrm{Th}-\mathrm{Pb}$ monazite ages of $\sim 53 \mathrm{Ma}$, indicating that anatexis occurred at this level of the metamorphic pile at $\sim 48-53 \mathrm{Ma}$, and that the NSZ was still active after this age range.

Additional Th- $\mathrm{Pb}$ monazite and ${ }^{40} \mathrm{Ar} /{ }^{39} \mathrm{Ar}$ mica ages point to ongoing or renewed shearing, under greenschist facies conditions, at $\sim 33 \mathrm{Ma}$.

Jahn-Awe et al. (2010) have studied an area in southwestern Bulgaria thought to expose the northwestern extension on the NSZ (Fig. 1). According to this work, based on $\mathrm{U}-\mathrm{Pb}$ zircon dating of plutonic rocks, thrusting along the NSZ occurred at some time between 56 and $32 \mathrm{Ma}$. The older age bound stems from the observation that $56 \mathrm{Ma}$ old granites 
emplaced at higher levels of the SU contain inherited zircons with ages typical of this unit but no age typical of the underlying PU. From this, Jahn-Awe et al. (2010) infer that the PU was not yet present underneath the area at $56 \mathrm{Ma}$ and, thus, was underthrust later. The strength of the argument is questionable because the PU in this area is characterized by an upper greenschist to lower amphibolite facies metamorphic grade and none of its gneisses ever reached the conditions of anatexis. Hence, there is no strong reason to expect zircons extracted from this unit in a pluton. As shown by their inherited zircon content, the $56 \mathrm{Ma}$ old granites likely formed from melts produced in the $\mathrm{SU}$, which is in line with the migmatitic nature of this unit.

Nagel et al. (2011) have studied the central segment of the NSZ and proposed the following three-stage scenario. Firstly, based on the age data of Liati and Gebauer (1999), Liati (2005) and Kirchenbaur et al. (2012), at least part of the SU experienced eclogite facies metamorphism at $\sim 42-51 \mathrm{Ma}$ (see Sect. 2.1). Secondly, high-temperature synmetamorphic thrusting developed, resulting in the aforementioned inverted metamorphic sequence. In sheared migmatites at higher levels of the NSZ, a leucosome has yielded one U-Pb zircon age of $\sim 39 \mathrm{Ma}$ (Liati, 2005). Based on this age, thrusting is inferred to have been active until $39 \mathrm{Ma}$. Thirdly, the status of the NSZ drastically changed as top-to-SW shearing developed as a result of extensional tectonics. The shear fabric of the NSZ would reflect this third stage. In support to this view, Nagel et al. (2011) report that migmatization at higher levels of the NSZ is strictly pre-kinematic. Top-to-SW shearing is interpreted to result from extension because syn-shearing exhumation is recorded by rocks located in the footwall of the NSZ (i.e., within the PU). Extensional shearing would have been active during the Late Eocene, from $\sim 39$ to $\sim 33 \mathrm{Ma}$. As a result, a peculiar aspect of the scenario of Nagel et al. (2011) is that the NSZ changed its status from being a thrust, then an extensional shear zone, in $1 \mathrm{Myr}$ or so. The same feature has been proposed in other scenarios, the sudden switch occurring at $\sim 37-38 \mathrm{Ma}$ (Gautier et al., 2001; Krohe and Mposkos, 2002).

The above review shows that the NSZ has been the subject of contrasting interpretations while it is a key object for understanding the Cenozoic evolution of the RMC. The latter, in turn, is a key issue for deciding whether Alpine orogeny involved distinct periods of crustal accretion or only a Mesozoic cycle followed by Cenozoic extension triggered by mantle delamination.

\section{The Nestos Shear zone}

The NSZ runs with a mean WNW-ESE strike across the southern central part of the RMC (Fig. 1). All authors agree that the shear zone dips to the NNE and that its main fabric has top-to-SW kinematics. The segment of the NSZ joining Xanthi to the northern flank of Falakron Mountain has been the topic of most studies. In this area, two cross-sections are especially useful for studying the shear zone. The one in the east runs along the Xanthi River, north of Xanthi (e.g., Kronberg and Raith, 1977; Barr et al., 1999). The one in the west follows the road from Drama to Sidironero (Fig. 2). Thereafter it is named the Drama-Sidironero cross-section (DSCS). Figure 3 shows

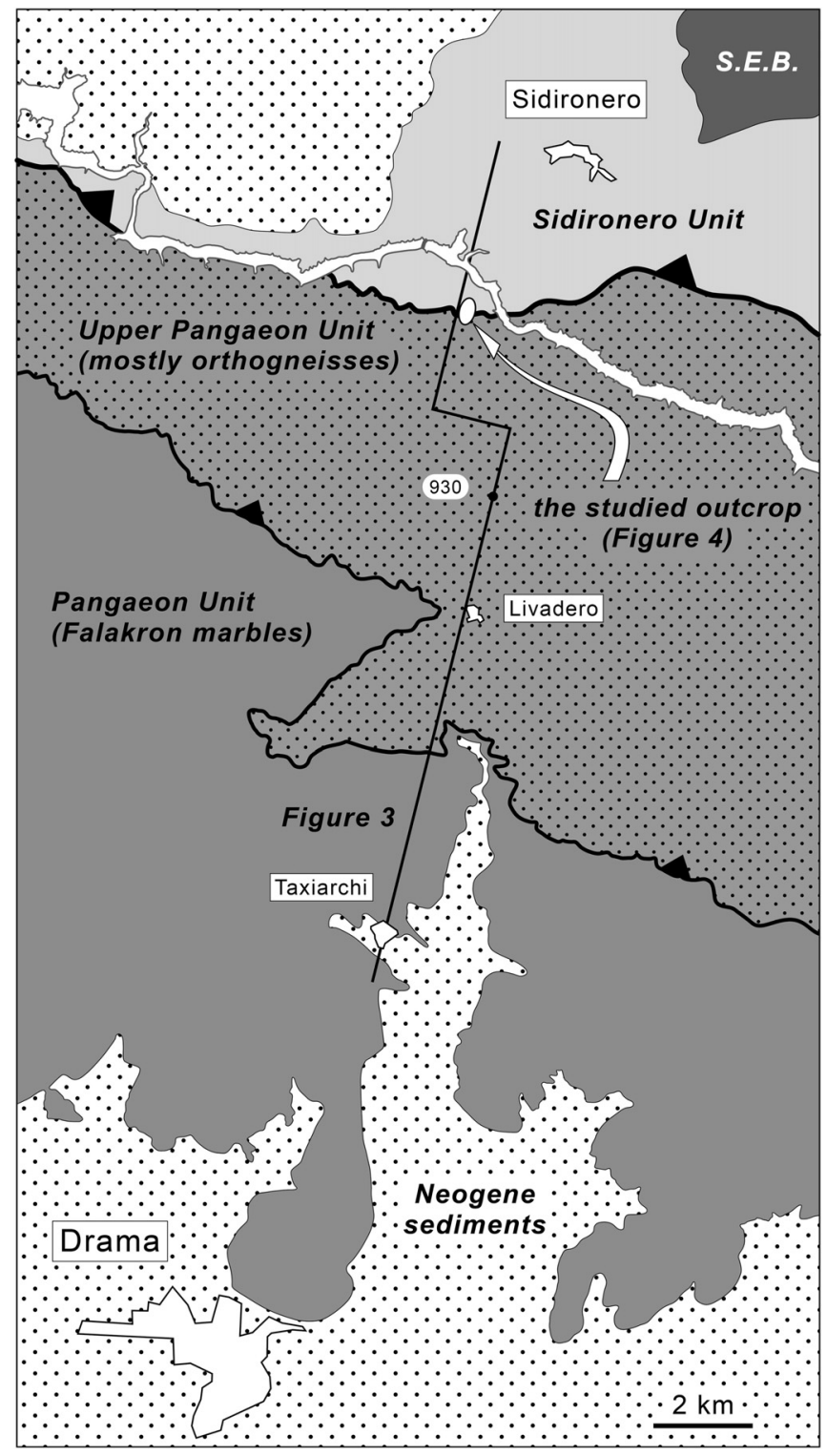

Fig. 2. Simplified geological map of the study area, located in Figure 1. Contours are adapted from Jordan (1969) and Dimadis and Zachos (1986) and modified according to our observations in the field and on satellite images. S.E.B. is the southwestern margin of the Skaloti-Echinos Batholith.

this cross-section according to our observations and field measurements. Other versions of the DSCS are found in Zachos and Dimadis (1983), Mposkos et al. (1998), Turpaud and Reischmann (2010), and Nagel et al. (2011).

The metamorphic pile exposed along the NSZ is usually subdivided into two or three structural units separated by major tectonic contacts. As mentioned in Section 2, Papanikolaou and Panagopoulos (1981) initially distinguished a lower unit and an upper unit, later named the PU and SU, respectively.

The Falakron marbles, reaching a thickness of about $6 \mathrm{~km}$ in Falakron Mountain (Jordan, 1969), form a salient feature of the PU. Deeper levels of the metamorphic pile mostly consist of orthogneisses and minor metabasites. $\mathrm{Pb}-\mathrm{Pb}$ evaporation 


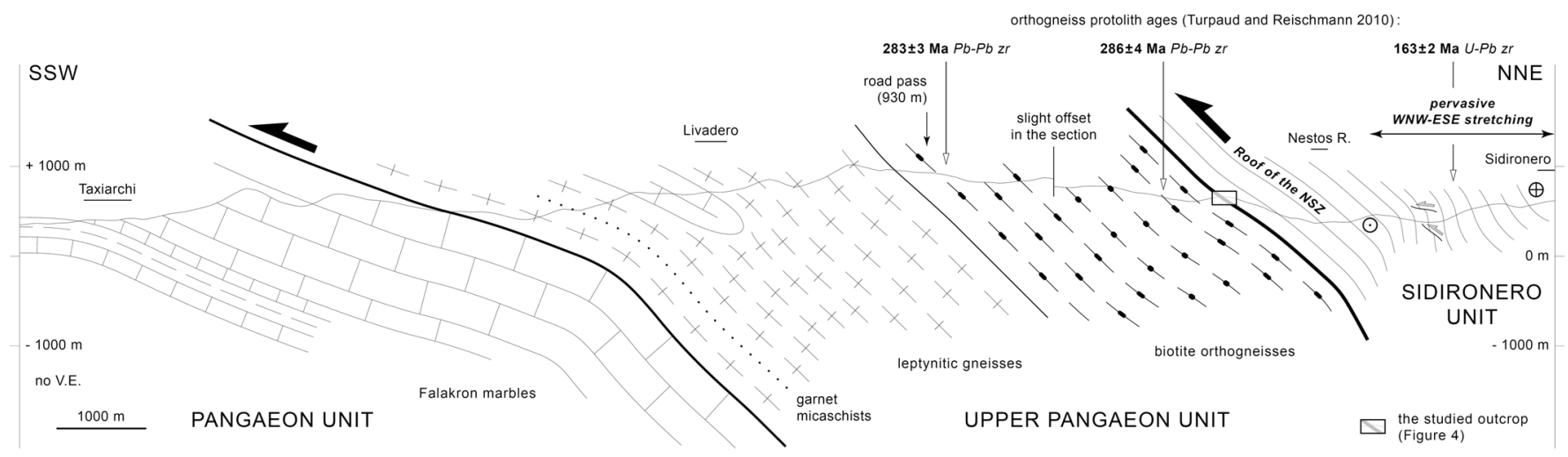

Fig. 3. The Drama-Sidironero cross-section (DSCS) as inferred from our field observations and measurements (location in Fig. 2).

dating of zircons documents early Permian ages $(\sim 270$ $285 \mathrm{Ma}$ ) for the magmatic protolith of the gneisses (Turpaud and Reischmann, 2010). The origin of the contact between the orthogneisses and the overlying Falakron marbles is difficult to determine due to the intense ductile deformation that affects the whole rock pile. Our observations in a structural window west of Xanthi show that this contact is locally underlined by quartzites, calcschists, and few micaschists, suggesting that the gneisses represent the original basement of a sedimentary pile that started with limited terrigenous accumulations.

The main tectonic contact associated with the NSZ, i.e., the contact between PU and SU, has initially been placed along the roof of the Falakron marbles (Papanikolaou and Panagopoulos, 1981; see also, e.g., Dinter, 1998). While this is roughly acceptable in the area of Xanthi (Fig. 1), it is not further west where a large part of the metamorphic pile above the Falakron marbles shows greater affinities with the underlying orthogneisses than with rocks of the SU (e.g., Mposkos et al., 1998; Turpaud and Reischmann, 2010) (Fig. 2). Along the DSCS (Fig. 3), the first $5.4 \mathrm{~km}$ of the metamorphic series above the Falakron marbles are dominated by leptynitic and overlying mesocratic, occasionally porphyritic, biotite orthogneisses closely resembling those visible further south and east beneath the Falakron marbles. The correlation is supported by $\mathrm{Pb}-\mathrm{Pb}$ evaporation dating of zircons which also documents early Permian ages $(\sim 285 \mathrm{Ma})$ for the magmatic protolith of these gneisses (Turpaud and Reischmann, 2010) (Fig. 3). Hence, these orthogneisses are part of the "Pangaeon" rock pile (Mposkos et al., 1998; Turpaud and Reischmann 2010; Nagel et al., 2011). Nevertheless, the roof of the Falakron marbles probably coincides with an important tectonic contact, as originally proposed by Papanikolaou and Panagopoulos (1981). Therefore, we separate this $5.4 \mathrm{~km}$ thick pile of rocks from the PU and refer to it as the Upper Pangaeon Unit (UPU) (Figs. 2 and 3). Our UPU is roughly equivalent to the "Albite Gneiss Series" of Krohe and Mposkos (2002).

Higher levels of the SU are dominated by biotite orthogneisses. $\mathrm{U}-\mathrm{Pb}$ and $\mathrm{Pb}-\mathrm{Pb}$ zircon dating documents ages of $\sim 135-165 \mathrm{Ma}$ for their magmatic protholiths (Turpaud and Reischmann, 2010). In Figure 3, this is illustrated by the orthogneiss with a U-Pb zircon age of $163 \pm 2 \mathrm{Ma}$ near Sidironero. Lower levels of the SU consist of a layered mélange containing various types of gneiss, marbles, and metabasites (e.g., Barr et al., 1999; Turpaud and Reischmann,
2010). It includes migmatitic gneisses (e.g., Liati, 2005; Bosse et al., 2009), retrogressed eclogites (e.g., Liati, 1986; Schmidt et al., 2010), and garnet-kyanite metapelites hosting microdiamond inclusions (e.g., Mposkos and Kostopoulos, 2001; Schmidt et al., 2010). In the Xanthi section, the mélange is $\sim 3 \mathrm{~km}$ thick and includes the $48-53 \mathrm{Ma}$ old pegmatites dated by Bosse et al. (2009) (see Sect. 2.2). These pegmatites also contain inherited zircon grains with features documenting their growth during medium- to high-grade metamorphism and U$\mathrm{Pb}$ ages between $\sim 120$ and $\sim 160 \mathrm{Ma}$ (Bosse et al., 2009). The garnet-kyanite metapelites of the Xanthi section have yielded one $\mathrm{U}-\mathrm{Pb}$ zircon age of $149 \pm 2 \mathrm{Ma}$, interpreted as dating conditions close to the peak of UHP metamorphism (Liati, 2005), and another U-Pb zircon age of $144 \pm 2 \mathrm{Ma}$, interpreted as dating post-UHP high-temperature metamorphism (Krenn et al., 2010). Two samples of garnet-kyanite micaschist from the mélange south of Sidironero have yielded U-Th-Pb monazite ages spread between $\sim 120$ and $\sim 170 \mathrm{Ma}$ and a mean age of $142 \pm 11 \mathrm{Ma}$ interpreted as dating upper amphibolitegranulite facies conditions (Didier et al., 2014). Thus, lower levels of the SU experienced mid-Mesozoic high-grade metamorphism.

In the case of the DSCS, the layered mélange at the base of the SU is located on the southern flank of the Nestos River Valley (Turpaud and Reischmann, 2010; Schmidt et al., 2010) (Fig. 2). This area also displays a transition from migmatitic gneisses, above, to non-migmatitic gneisses, below (e.g., Zachos and Dimadis, 1983). This transition has been used as the primary argument for siting the contact between the SU and (U) PU at this level of the metamorphic pile (Mposkos et al., 1998). U-Pb zircon dating of a leucosome in a migmatitic orthogneiss has yielded an age of $294 \pm 2$ Ma for the magmatic protolith of the gneiss and an age of $\sim 39 \mathrm{Ma}$ (based on two analyses) for the formation of the leucosome (from narrow rim domains interpreted as having crystallized during migmatization) (Liati, 2005).

For most authors, the downward transition from migmatitic to non-migmatitic gneisses is an element of the inverted metamorphic sequence that characterizes the NSZ (Kronberg and Raith, 1977; Papanikolaou and Panagopoulos, 1981; Zachos and Dimadis, 1983; Kotopouli et al., 1991; Mposkos et al., 1998; Barr et al., 1999; Nagel et al., 2011). At lower levels of the DSCS, Jordan (1969), Birk (1970), and Zachos and Dimadis (1983) have described a downward transition 
from lower-amphibolite to upper-greenschist facies assemblages, providing additional evidence for an inverted metamorphic sequence. Jordan (1969) and Birk (1970) report the metamorphic assemblages as having crystallized during ductile shearing and the concurrent development of isoclinal folds with NE-SW-trending axes. According to Krohe and Mposkos (2002), lower levels of the "Albite Gneiss Series" (equivalent to our UPU) experienced peak pressures of $\sim 11 \mathrm{kbar}$ at $\sim 500^{\circ} \mathrm{C}$, then reached a temperature climax of $\leq 580^{\circ} \mathrm{C}$ during decompression down to around $6-7 \mathrm{kbar}$. Along the DSCS, from a leucocratic gneiss and a metabasite collected just above the Falakron marbles, Nagel et al. (2011) have deduced a P-T path involving peak pressures of 9-10 kbar at $\sim 450^{\circ} \mathrm{C}$, as determined from pre-kinematic assemblages, and a decompression path reaching $\sim 4 \mathrm{kbar} / \sim 520^{\circ} \mathrm{C}$, associated with the main top-to-SW shear fabric.

Contrasting opinions exist for the relations between migmatization and top-to-SW shearing at higher levels of the NSZ. Based on the Xanthi section, Kronberg and Raith (1977) and Barr et al. (1999) have argued that migmatization was syn- to late-kinematic. This is in line with the field aspect of some of the pegmatite veins interpreted as draining local melts (Bosse et al., 2009). In contrast, the layered mélange of the DSCS has been used to infer that migmatization was prekinematic. According to Turpaud and Reischmann (2010), the migmatites in this part of the DSCS are found within large boudins surrounded by mylonites associated with top-to-SW shearing, suggesting that migmatization is older than shearing. Nagel et al. (2011) share the same opinion, based on the observation that leucosomes are consistently boudinaged in the solid state. For these authors, the shear fabric of the NSZ postdates inverted metamorphism and does not reflect thrusting but extensional shearing.

Within the mélange of the DSCS, from a sample of garnetkyanite micaschist, P-T conditions of $8-12 \mathrm{kbar}$ and 650 $750^{\circ} \mathrm{C}$ have been determined for the development of the topto-SW shear fabric (Turpaud, 2006, his thin section F101-2). From a similar sample hosting microdiamond inclusions in the garnets, conditions of $8-10 \mathrm{kbar}$ and $600-750^{\circ} \mathrm{C}$ have been determined for the assemblage associated with deformation (Schmidt et al., 2010). These temperature estimates for the conditions prevailing during top-to-SW shearing are significantly higher than those at lower levels of the DSCS (see above). Thus, they seem to contradict the opinion of Nagel et al. (2011) that top-to-SW shearing postdates the development of the inverted metamorphic sequence. The garnetkyanite micaschists studied by Didier et al. (2014) are from the same locations where Turpaud (2006) and Schmidt et al. (2010) collected their samples. They have yielded U-Th- $\mathrm{Pb}$ monazite ages between $\sim 120$ and $\sim 170 \mathrm{Ma}$ (see above) as well as an age of $36.3 \pm 1.5 \mathrm{Ma}$. The latter is yielded by a distinct generation of yttrium-rich monazite found in the schistose matrix of the samples, outside the garnet and kyanite porphyroclasts.

\section{Field observations and sampling}

The outcrop studied here is located along the DSCS (Figs. 2 and 3), at the level of the section showing a transition between non-migmatitic and migmatitic gneisses, which most authors take as the locus of the contact between the UPU and SU (see Sect. 3). The outcrop extends for about $300 \mathrm{~m}$ along a large curve of the road joining Livadero to Sidironero (Fig. 4). The outcrop and adjacent exposures show NE-dipping foliations concordant with those observed across the NSZ (Fig. 3).

Moving northeastward (i.e., up-section) along the road, the first exposed rocks are biotite orthogneisses similar to the $\sim 2 \mathrm{~km}$ thick pile of rocks forming the upper part of the UPU (Fig. 3). Mesocratic, occasionally porphyritic orthogneisses dominate, but concordant layers of leucocratic gneisses are also present. None of these gneisses display signs of migmatization. Overlying these gneisses, a $\sim 30 \mathrm{~m}$ thick pile of migmatitic gneisses is exposed, thereafter referred to as part A of the outcrop (Fig. 4). Some gneisses show a welldeveloped layering defined by light grey mesosome/paleosome, centimeter thick coarse-grained quartz-feldspar leucosomes, and millimeter thick biotite-rich melanosomes (Fig. 5a). In other gneisses, the migmatitic compositional layering is less pronounced and with more diffuse boundaries (Fig. 5b). The migmatitic layering parallels the dominant NEdipping foliation of the outcrop. Coarser-grained leucosomes have an irregular thickness, which likely results from solidstate boudinage (Fig. 5a). Both the layering and the main foliation are affected by numerous centimetric (Fig. 5b) to metric (Fig. 5c) tight asymmetric folds. The asymmetry of the folds is consistent with ductile shearing with a top-to-SW sense of shear. As a result, the aspect of most rocks in A seems compatible with the hypothesis that migmatization preceded top-to-SW shearing. However, few leucosomes are also found that document syn- to late-kinematic migmatization. Figure 6a illustrates the case of a syn-kinematic leucosome, with diffuse margins and a weak internal fabric, crosscutting at a low angle the NE-dipping migmatitic layering. Figure $6 \mathrm{~b}$ and $\mathrm{c}$ illustrate the case of steeply-dipping late-kinematic pegmatoid leucosomes. They also have diffuse margins and connect without visible discontinuity to adjacent foliation-parallel leucosomes. The latter show evidence for solid-state deformation such as quartz grains with deeply indented boundaries (Fig. 6d). This indicates that these leucosomes do not represent post-kinematic melt injections. In the view of Figure $6 \mathrm{~b}$, the left leucosome, sampled as "P10-8", forms a thick massive vein. In the right leucosome (Fig. 6c), an axial core made of quartz is reminiscent of structures frequently seen in differentiated pegmatite veins. This suggests that at least some of the pegmatoid leucosomes were formed after the peak production of melt, when the host rocks still contained some interstitial melt or/and fluid. The thick white line in Figure $6 \mathrm{~b}$ delineates the shape of a pair of open folds flanking the right vein. These folds resemble paired hook folds (Hudleston, 1989) or a-type (or possibly ntype) flanking folds (Passchier, 2001; Grasemann et al., 2003). Following this interpretation, the vein was likely formed as a low-dipping tension gash collecting late interstitial melts, then it rotated during ongoing top-to-SW shearing to end up with a steep dip and a pair of flanking folds (Fig. 6e). Thus, although they crosscut the NE-dipping foliation, the steep leucosomes of Figure 6b represent syn or late-kinematic structures with respect to the main top-to-SW shearing deformation, in line with the record in the contiguous foliation-parallel leucosomes. 


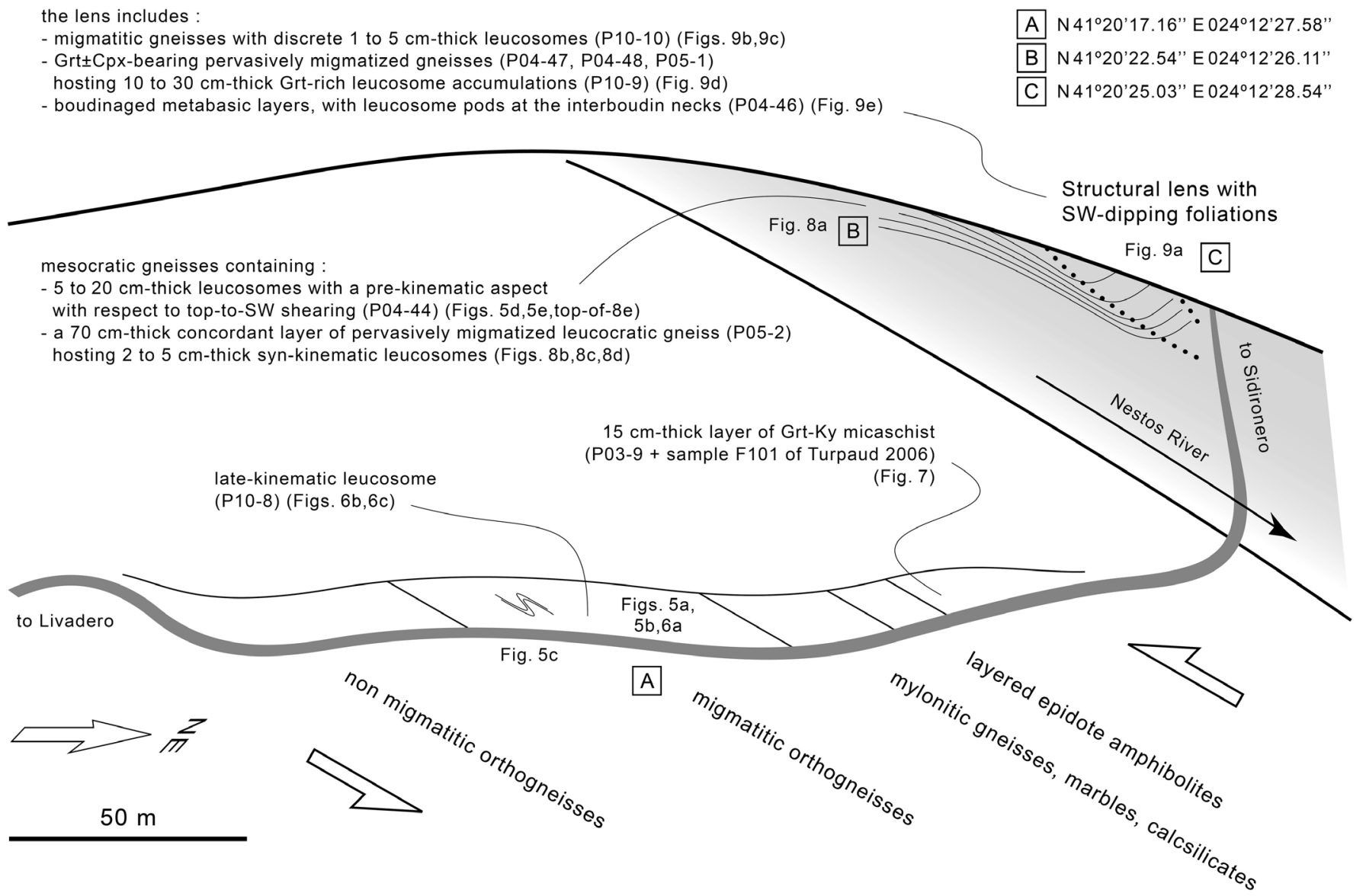

Fig. 4. Sketched oblique aerial view of the studied outcrop (located in Figs. 2 and 3) with a report of the main features, the location of samples, and the location of the field views of Figures 5 to 9.

The contact between the migmatitic gneisses of $\mathrm{A}$ and the underlying non-migmatitic gneisses is non impressive and does not seem to coincide with a zone of particularly high strain. In contrast, higher levels of A show a transition, within about one meter, to dark, finely layered mylonitic gneisses. The rock sequence overlying A consists of such gneisses together with minor marble and calcsilicate horizons, followed by well layered epidote-rich amphibolites. The amphibolites are overlain by dark gneisses hosting a $15 \mathrm{~cm}$ thick horizon of garnet-kyanite micaschist from which Turpaud (2006) extracted his sample F101; we sampled the same horizon as "P03-9" (Figs. 4 and 7). This lithology shows asymmetric shear bands documenting a top-to-SW sense of shear (Fig. 7a). Eiotite asymmetric strain shadows around the garnet porphyroclasts indicate the same kinematics (Turpaud, 2006). The flanks of the porphyroclasts opposed to the shear sense are enriched in iron oxides, which we interpret as the result of enhanced dissolution in the direction of maximum stress (Fig. 7b). Biotite-filled fractures cutting across the largest garnets have an orientation consistent with their interpretation as tension gashes opened during the top-to-SW shearing deformation. The variegated layered sequence overlying $A$ is $\sim 30 \mathrm{~m}$ thick, higher levels of the section being obscured by scree deposits along the main curve of the road.
The next exposure, after the curve, consists of two parts. The largest part shows NE-dipping foliations and is best exposed near the top of the hill (part B of the outcrop, Fig. 4). It is dominated by mesocratic gneisses that contain abundant lens-shaped pegmatoid veins up to $20 \mathrm{~cm}$ in thickness. Most veins are fringed by $1-5 \mathrm{~mm}$ thick biotite-rich selvedges (Fig. 5d, e) that occasionally include tiny garnets. One such vein has been sampled as "P04-44" (Fig. 8a). The discontinuous nature of the veins results in part from their boudinage in the solid state (Fig. 5d). Nevertheless, the fairly regular distribution of the lensoid veins within the gneiss mass (e.g., in the lower part of Fig. 8a) suggests that this discontinuous nature is also an original feature. This, in turn, suggests that the veins originate from melt drainage on a local $(\sim 1-10 \mathrm{~m})$ scale. In line with this view, the pegmatoid veins are restricted to the mesocratic gneisses and do not penetrate other rock types such as the $70 \mathrm{~cm}$ thick concordant layer of leucocratic gneiss seen in Figure 8a. Hence, the pegmatoid veins can be interpreted as leucosomes. The thin mafic selvedges along their margins may represent a solid residuum left after partial melting and melt segregation, or zones of chemical reaction at the interface between the leucosomes and the host gneiss after melt crystallization (e.g., Sawyer, 2008). Post-migmatization top-to-SW shearing is documented by solid-state asymmetric boudinage of the veins (Fig. 5d) and the 


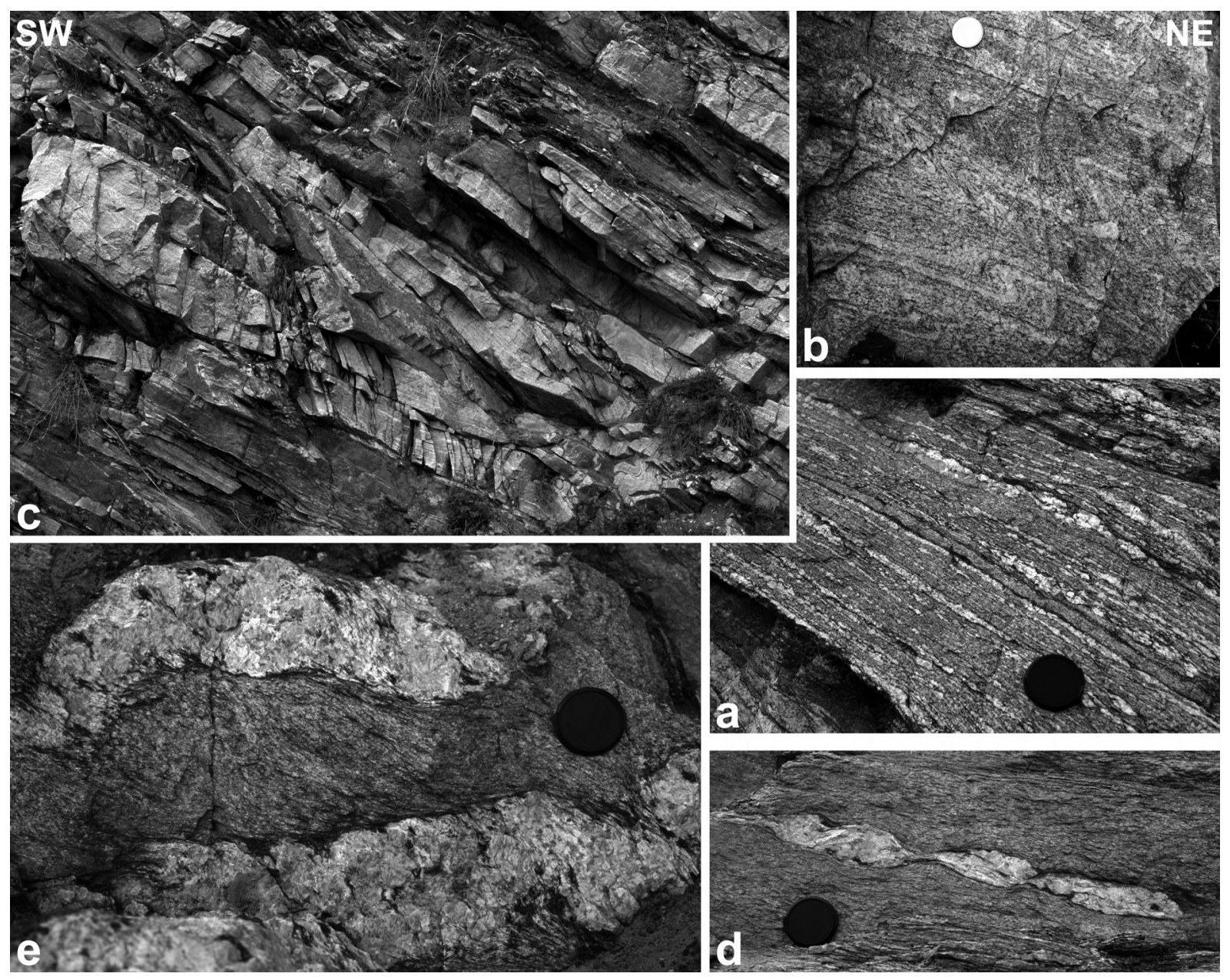

Fig. 5. Field views of the most common types of migmatitic rocks in part A (a-c) and part B (d, e) of the outcrop (locations in Fig. 4). The lens cap is $5 \mathrm{~cm}$ in diameter.

refraction of foliations across their margins (Fig. 5e). Under the microscope (Fig. 8f), the pegmatoid assemblage of P04-44 consists of:

- plagioclase completely recrystallized into elongate aggregates with a granoblastic polygonal fabric;

- ribbons of recrystallized quartz with deeply indented boundaries and a much larger grain size than in adjacent plagioclase aggregates;

- K-feldspar clasts showing undulose extinction, partly recrystallized into aggregates with similar features as in the case of plagioclase.

K-feldspar recrystallization has developed along few deformation bands within the clasts and along the rims of the clasts where myrmekites are also present (e.g., in the lower left of Fig. 8f). These features document deformation under high-grade conditions, at temperatures of at least $\sim 650^{\circ} \mathrm{C}$ (e.g., Trouw et al., 2010).

A distinct situation is met with the layer of leucocratic gneiss in Figure 8a, sampled as "P05-2". This layer is more pervasively migmatized than the adjacent mesocratic gneisses and hosts a network of $2-5 \mathrm{~cm}$ thick leucosomes. Most of these leucosomes dip northeastward at a slightly greater angle than the main foliation. The foliation within and along the margins of the layer of leucocratic gneiss displays a series of tight asymmetric folds that confirm a top-to-SW sense of shear (Fig. 8a, b). The northeast-dipping leucosomes are not folded and, instead, parallel the axial plane of the folds (Fig. 8b-d). This feature is quite usual in syn-kinematic migmatites (e.g., Vernon and Paterson, 2001; Weinberg and Mark, 2008). The leucosomes display an internal foliation subparallel to their walls and occasionally crosscut the short limb of some of the SW-vergent folds (Fig. 8c, d). Hence, at least some of the thin leucosomes seen in Figure $8 \mathrm{a}$ can be interpreted as being located along reverse-sense shear bands ("type 1" segregations of Sawyer, 2000) while the adjacent folds may be described as S-type flanking folds formed through mechanism Ic of Passchier (2001). Thus, at least part of the migmatization in the leucocratic gneiss developed during the regional top-toSW shearing deformation. Although less abundant, northeastdipping thin leucosomes parallel to the axial plane of folds are also present within the mesocratic gneisses. Figure 8e shows such leucosomes, with diffuse margins, just beneath the thicker pegmatoid vein sampled as P04-44. This suggests that, at least locally, the mesocratic gneisses also experienced partial melting during the top-to-SW shearing deformation.

Further down the hill, close to the roadside, $a \sim 15 \times 25 \mathrm{~m}$ body of rocks displays foliations with a distinct southwestward 

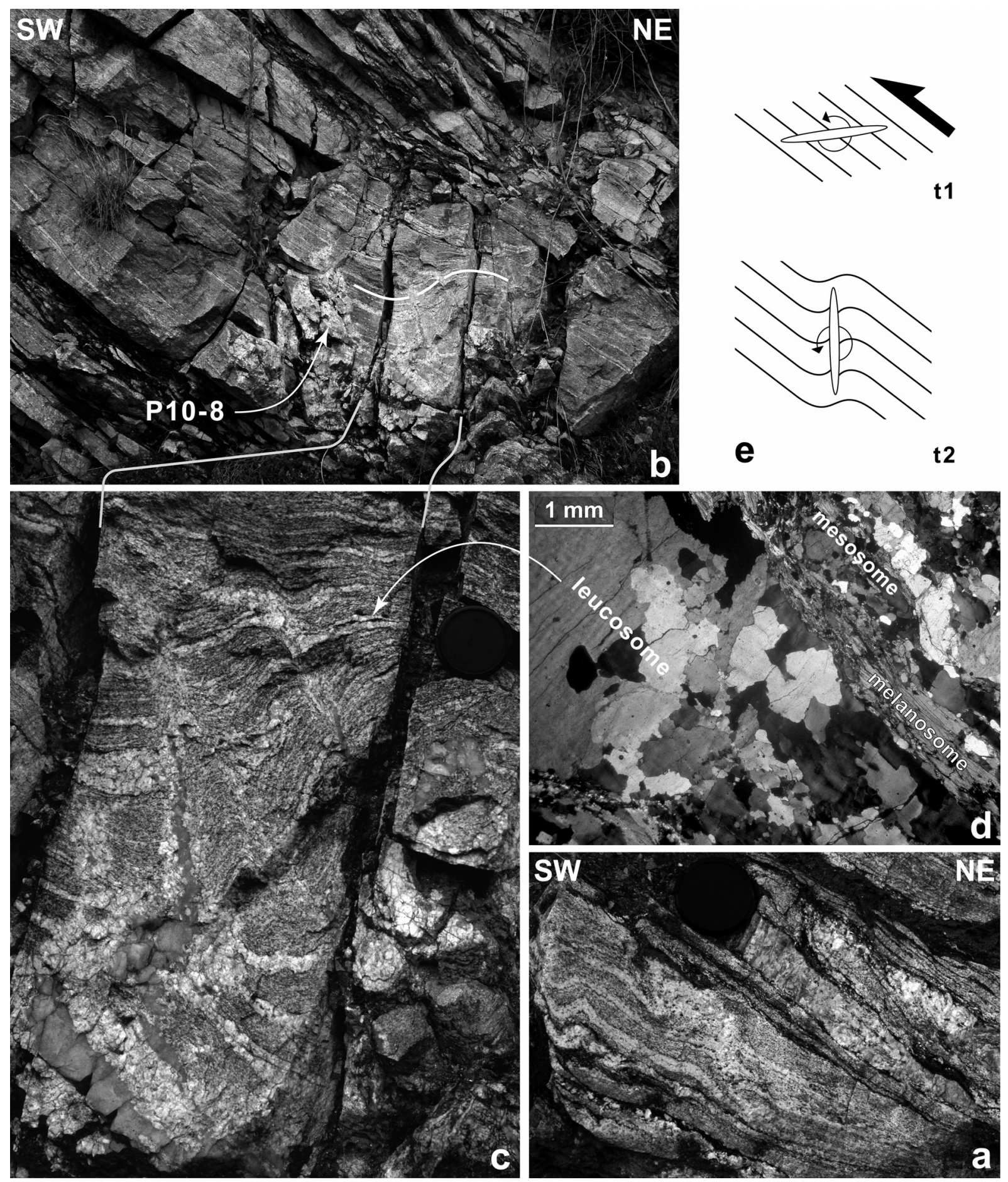

Fig. 6. Field views $(\mathrm{a}-\mathrm{c})$ and photomicrograph (d) in cross-polarized light of syn-kinematic leucosomes in part A of the outcrop (location in Fig. 4). (e) Two-step scenario accounting for the presence of paired hook folds (sensu Hudleston 1989) flanking the steep leucosome of Figure 6c (the paired folds are shown with a thick white line in Fig. 6b).

$\operatorname{dip}$ (part C of the outcrop, Figs. 4 and 9a). It consists of interlayered migmatized gneisses and dark amphibolites (Fig. 9b). Along the margins of the body, the internal SWdipping foliation is sharply bent into parallelism with the regional NE-dipping foliation. This bending is accompanied by a pronounced increase in solid-state deformation of the leucosomes (compare, e.g., Figs. 9c and 5e). This shows that the fabrics within the body are relictual with respect to the main top-to-SW shear fabric. Thus, the body can be interpreted as a structural lens. As the rock types within and outside the lens are the same, the contours of the lens do not seem to have been predetermined by the presence of a high-strength lithology (e.g., a large mafic body). The same picture arises from another $\sim 10 \mathrm{~m}$-scale structural lens exposed about $900 \mathrm{~m}$ 

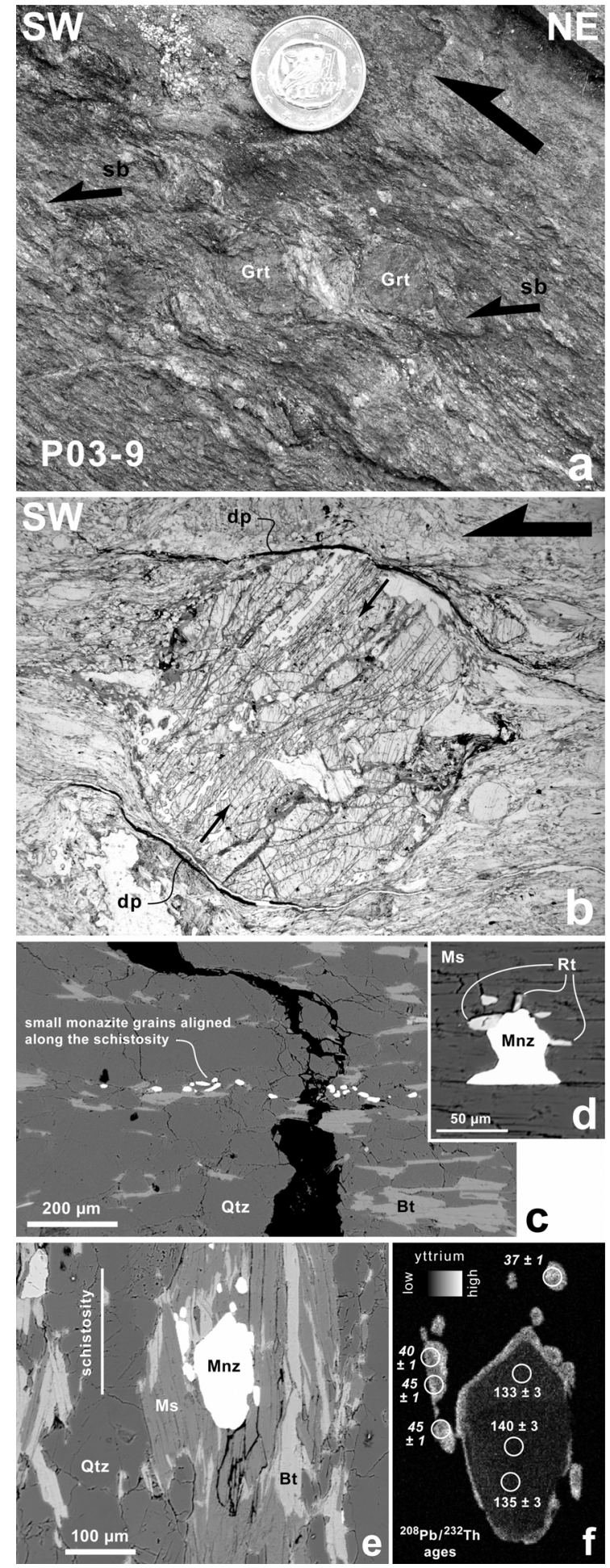

Fig. 7. Illustrations of the $15 \mathrm{~cm}$ thick layer of garnet-kyanite micaschist sampled as P03-9 (location in Fig. 4). (a) Field view (Grt, garnet; sb, shear band). (b) Photomicrograph centered on a garnet porphyroclast. Arrows highlight the orientation of the main set of fractures within the clast, some being filled with biotite; dp, iron oxide-enriched dissolution planes. (c-e) BSE images illustrating the relations between monazite grains and adjacent minerals in the schistosed matrix. (f) Yttrium X-ray map of the aggregate visible in Figure $7 \mathrm{e}$ and a report of the ${ }^{208} \mathrm{~Pb} /{ }^{232} \mathrm{Th}$ ages obtained by LA-ICPMS further northwest, on the way down to the Nestos River (Fig. 10a). This second lens consists of subvertically layered migmatitic gneisses in which the leucosomes have a poor internal fabric (Fig. 10b). The two lenses coincide with the "migmatitic boudins surrounded by mylonites" reported by Turpaud and Reischmann (2010, their figure 2b).

About $40 \%$ of the first lens consists of migmatized mesocratic gneisses hosting $1-5 \mathrm{~cm}$ thick discrete leucosomes almost continuously fringed by $\leq 1 \mathrm{~cm}$ thick melanosomes (Fig. 9b, c). This rock type has been sampled as "P10-10". Clusters of garnet grains a few millimeters large are present along the melanosomes. Most leucosomes parallel the main SW-dipping foliation and have an irregular thickness, which may partly result from boudinage. A few other leucosomes have a highly oblique orientation and are tightly folded with axial planes parallel to the main foliation, which attests for solid-state deformation of the leucosomes. Nevertheless, unlike outside the lens (Fig. 5d, e), many leucosomes within the lens show only a poor internal fabric, including along their winding contact with adjacent melanosomes (Fig. 9c). Locally, leucosome segregations with diffuse margins crosscut the main layering (e.g., in the upper centre of Fig. 9c). This suggests that, within the lens, the latest significant deformation occurred at temperature conditions at or just below the solidus of the migmatized gneisses. Another $\sim 20 \%$ of the lens consists of gneisses that are pervasively migmatized, in which $\leq 1 \mathrm{~cm}$ thick leucosomes form a dense foliation-parallel network (Fig. 9d). This rock type has been sampled as "P04-48" (garnet-bearing gneiss) and "P04-47" and "P05-1" (garnetclinopyroxene-bearing gneisses). Within this lithology, garnetrich leucosome accumulations form $\sim 10-30 \mathrm{~cm}$ thick lensoid bodies showing gradational contacts with the migmatitic host. One such body with a nearly massive internal structure has been sampled as "P10-9" (Fig. 9d). Finally, about 40\% of the lens consists of boudinaged amphibolitic layers. Poorly strained coarse-grained leucosome pods occupy the interboudin necks (Fig. 9e), confirming that migmatization and deformation were coeval in the lens. One of these pods has been sampled as "P04-46". The mineralogical assemblage of some of the amphibolites includes garnet. We have not studied this lithology but metabasic rocks located on the same outcrop have been described as preserving eclogite facies relics (Liati, 2005; Schmidt et al., 2010). Judging from the UTM coordinates given by Schmidt et al. (2010) for their garnetbearing retrogressed eclogite "Si3a", this sample likely comes from the lens.

The presence of garnet is a distinguishing feature of the migmatites within the lens (part $\mathrm{C}$ of the outcrop). Tiny garnets are also present in the thin mafic selvedges fringing the pegmatoid leucosomes in the mesocratic gneisses near the top of the hill (part B of the outcrop, e.g., along the rims of sample P04-44). In both cases, structural relations suggest that migmatization is pre-kinematic with respect to the main top-to-

dating, highlighting the existence of two generations of monazite. Ages in italics correspond to pits yielding discordant ${ }^{206} \mathrm{~Pb} /{ }^{238} \mathrm{U}_{-}{ }^{207} \mathrm{~Pb} /{ }^{235} \mathrm{U}$ ages; together with data from other grains, these ages define a linear trend in a Tera-Wasserburg diagram and yield a lower-intercept age of $36.3 \pm 1.5 \mathrm{Ma}$ for the second monazite generation (see Didier et al., 2014 for details). 

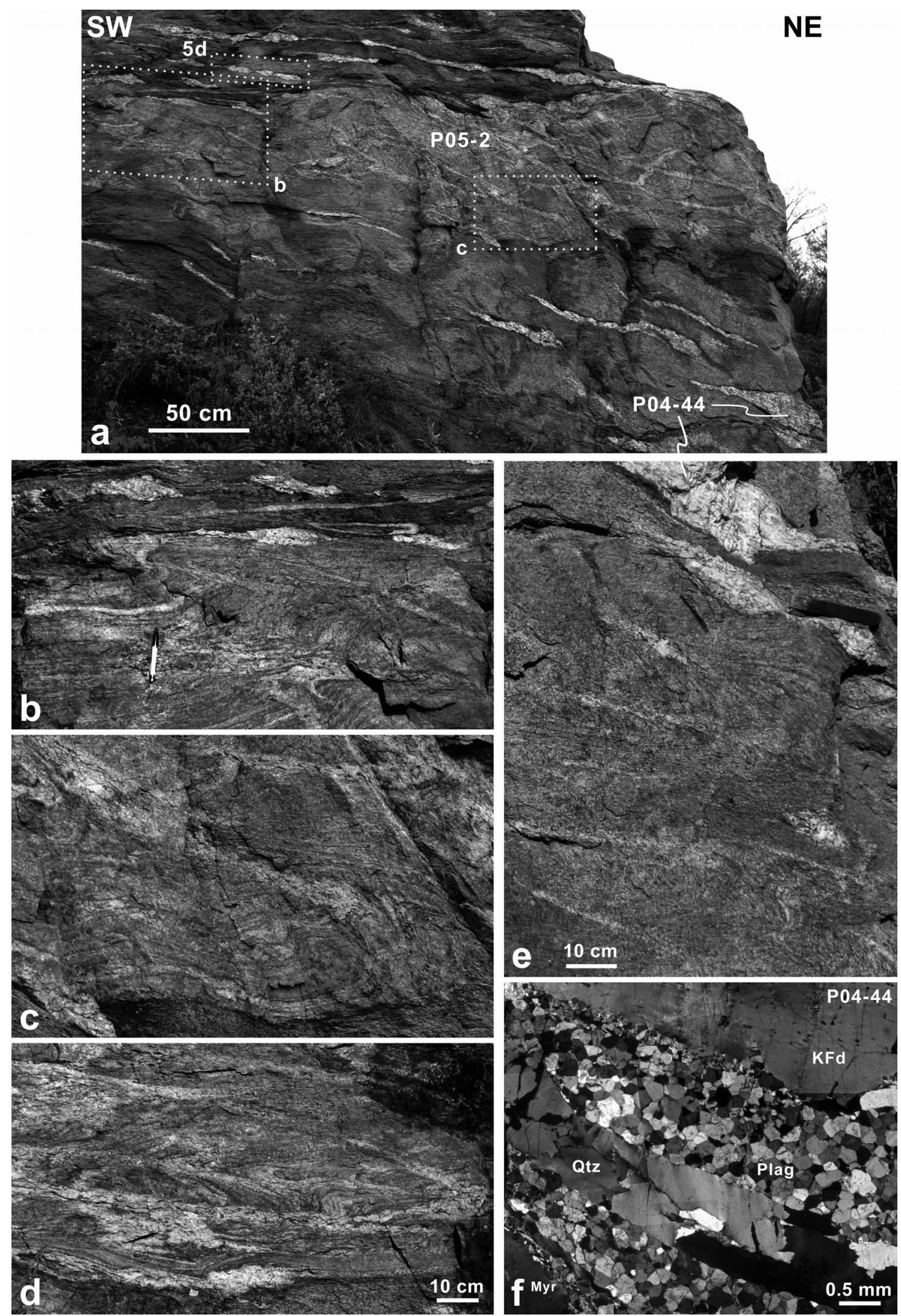

Fig. 8. (a) Field view of the main exposure in part B of the outcrop (location in Fig. 4), showing the presence of a $\sim 70 \mathrm{~cm}$ thick layer of leucocratic gneiss within mesocratic gneisses. (b-d) Closer views illustrating the presence of syn-kinematic leucosomes within the layer of leucocratic gneiss. (e) Closer view of the mesocratic gneisses in the vicinity of the pegmatoid vein sampled as P04-44, showing that thin syn-kinematic leucosomes are also present in these gneisses. (f) Photomicrograph of sample P04-44 in cross-polarized light (see the text for description). 


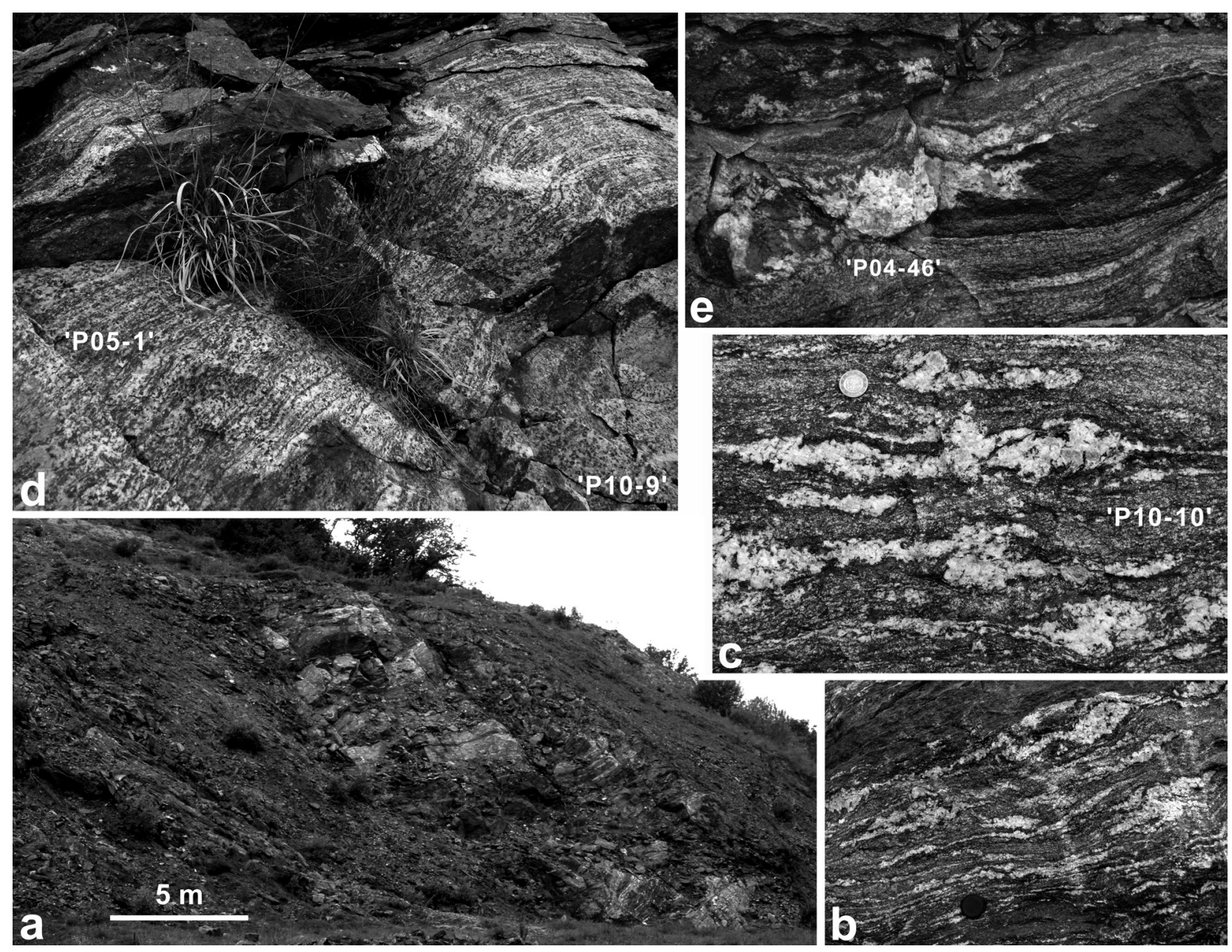

Fig. 9. Field views of part $\mathrm{C}$ of the outcrop, which consists of a structural lens with SW-dipping foliations (location in Fig. 4). See the text for details.

SW shear fabric. The existence of garnet in the related neosomes suggests that anatexis proceeded through biotite "dehydration" melting, at temperatures of at least $\sim 800^{\circ} \mathrm{C}$ (e.g., Vielzeuf and Montel, 1994; Stevens et al., 1997). For testing this hypothesis and for assessing the P-T conditions of migmatization, the petrology of four samples from the structural lens (P04-47, P04-48, P05-1, and P10-9) has been investigated. The results are given in Supplementary materials $\mathrm{S} 1$ and S2. In contrast, syn-kinematic migmatization, as observed in A (Fig. 6) and within the layer of leucocratic gneiss in B (Fig. 8), does not involve the growth of garnet or other possible peritectic anhydrous minerals that may result from dehydration melting reactions, such as sillimanite, cordierite, or orthopyroxene. In these migmatites, mesosome/paleosome, leucosome, and melanosome have similar assemblages that differ in mineral proportions only, involving plagioclase, $\mathrm{K}$ feldspar, quartz, biotite, and muscovite. This suggests relatively low-grade water-assisted partial melting. In line with this view, the few micaschist horizons of the outcrop contain abundant white mica underlining the main NE-dipping foliation. In the schistosed matrix of sample P03-9, few large white mica flakes are preserved as clasts (for instance, in the upper right corner of Fig. 7b) partly recrystallized into finer- grained muscovite and/or biotite (Fig. 7e) (see also Didier et al., 2014). In the garnet-kyanite micaschist sample "Si12b" of Schmidt et al. (2010), collected near the structural lens of Figure 10, the main top-to-SW shear fabric was formed while early phengites partly recrystallized into muscovite. Thus, the evidence suggests that metapelites did not experience muscovite dehydration melting, at least since the top-to-SW shear regime has been established. For pressures around 10 kbar (cf.Turpaud, 2006; Schmidt et al., 2010; see Sect. 3), this sets an upper bound for the temperature conditions during syn-kinematic migmatization at $\sim 750-800^{\circ} \mathrm{C}$ (e.g., Thompson, 1982; Gardien et al., 1995; Patiño Douce and Harris, 1998; White et al., 2001). A lower temperature bound is provided by the end-member hypothesis of water-saturated melting of granitic parent rocks, such as those met in A, which yields $\sim 615-635^{\circ} \mathrm{C}$ at $10 \mathrm{kbar}$ (e.g., Wyllie, 1983; Ebadi and Johannes, 1991). The obtained range of possible temperatures of migmatization during top-to-SW shearing, between $\sim 625^{\circ} \mathrm{C}$ and $\sim 750-800^{\circ} \mathrm{C}$, agrees with the estimates of 650-750 ${ }^{\circ} \mathrm{C}$ (Turpaud, 2006) and $600-750^{\circ} \mathrm{C}$ (Schmidt et al., 2010) for the development of this shear fabric within the garnet-kyanite micaschists. Microstructures in sample P04-44 (Fig. 8f) imply temperatures of at least $\sim 650{ }^{\circ} \mathrm{C}$ during 

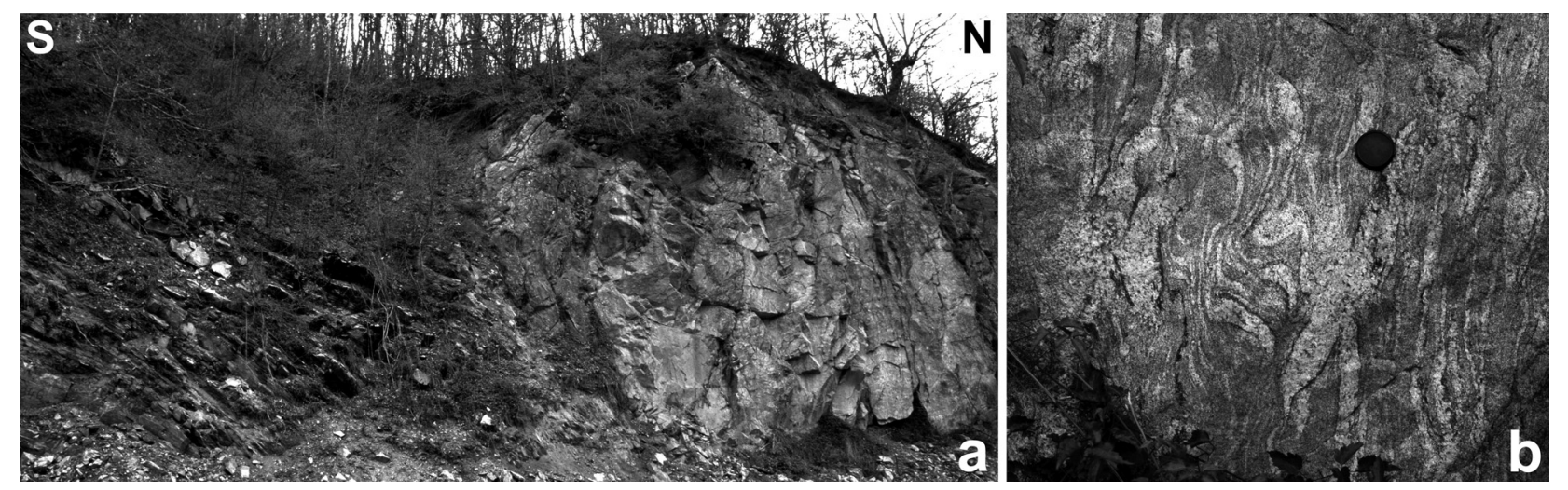

Fig. 10. Field views of a second structural lens exposed on the roadside about $900 \mathrm{~m}$ northwest of the lens shown in Figure 4.

deformation (e.g., Trouw et al., 2010), consistent with the above temperature range.

Summarizing field observations, the studied outcrop displays evidence for two partial melting events. The first event is pre-kinematic with respect to the main top-to-SW shear fabric and seems to have involved high-grade $\left(\geq 800^{\circ} \mathrm{C}\right)$ conditions (see Supplementary material S1 for a petrological analysis of related rocks). This first event is identified in the structural lens $\mathrm{C}$ and, to a less extent (due to the later top-toSW shear deformation), in B. The second anatectic event occurred during top-to-SW shearing and involved lower-grade $\left(<800^{\circ} \mathrm{C}\right)$ conditions. This second event is well expressed in A and, more locally, in B. Such a two-stage scenario could reflect a polycyclic tectono-metamorphic evolution, but it may also correspond to two successive stages of a single metamorphic cycle. In garnet-kyanite micaschists such as sample $\mathrm{P} 03-9$, U-Th-Pb monazite dating has yielded two groups of ages separated by a long time laps $(\geq 85 \mathrm{Myr}$, between $\sim 120-170 \mathrm{Ma}$ and $\sim 35 \mathrm{Ma}$ ) (Didier et al., 2014). Based on petro-geochemical arguments, Didier et al. (2014) interpreted the first age range as dating upper amphibolitegranulite facies conditions and the second age as related to the circulation of fluids released during the crystallization of anatectic melts. Thus, the older monazite generation may relate to the earlier, higher-grade partial melting event, and the younger monazite generation may relate to the later, lowergrade partial melting event. As discussed by Didier et al. (2014), the young, yttrium-rich monazites consist of smaller grains that grew during ductile shearing in association with fine-grained synfolial biotite (Fig. 7c, e, f). Hence, both the monazites and the leucosomes of the younger generation are syn-kinematic with respect to the top-to-SW shear fabric, supporting the hypothesis that they record the same event. Another argument for linking the younger monazite generation to a partial melting event is the U-Pb age of $~ 39 \mathrm{Ma}$ obtained on zircon rims in a leucosome of the same outcrop (Liati, 2005). However, the field picture portraying the corresponding migmatite (Liati, 2005, her figure 4) shows an exposure that is located within the structural lens $\mathrm{C}$ ( $c f$. the right part of Fig. 9b). This could suggest that the pre-kinematic highergrade partial melting event is not mid-Mesozoic but Eocene, in conflict with the above scenario. In order to assess more accurately the timing of the two anatectic events, we have gathered $\mathrm{U}-\mathrm{Th}-\mathrm{Pb}$ geochronological data on the samples in bold type in the above description, forming a collection of leucosomes and migmatized gneisses from the different parts of the outcrop.

\section{LA-ICPMS dating}

U-Th-Pb geochronology has been carried out by LA-ICPMS on separated minerals (zircon, monazite, and rutile) except for two samples (P04-47 and P05-1) in which zircons were analyzed in thin section. Zircons, monazites, and rutiles were separated under the microscope, mounted in epoxy blocks and polished for analysis. Prior to analytical work, the internal structure of the grains has been investigated using cathodoluminescence (CL) or back scattered electron (BSE) imaging. The analytical methods are described in Supplementary material S3. All data are quoted at the $2 \sigma$ level and reported in Supplementary material S4.

\subsection{Samples from part $\mathrm{C}$ of the outcrop}

Zircons separated from samples P10-10, P10-9, and P04-46 reveal similar features (Fig. 11a-c). They are rounded or isometric crystals with "soccerball" or "multi-faceted" shapes, which is typical of zircons grown during hightemperature anatexis with low water activity (Harley et al., 2007). Large prismatic crystals are also present but rare. Most measured ${ }^{206} \mathrm{~Pb} /{ }^{238} \mathrm{U}$ ages are mid-Mesozoic $(\sim 120-160 \mathrm{Ma})$ while older ages $(\sim 180 \mathrm{Ma}$ and more) have been obtained in few inherited cores (e.g., in grains P10-10-58 and P10-9-40). The mid-Mesozoic domains exhibit sector zoning and planar banding, which is usual in zircons cristallized from anatectic melts and/or formed during high-temperature metamorphism (Harley et al., 2007). Some mid-Mesozoic grains show older ages in the core and younger ages in the rims (e.g., grains P10-10-26, P10-9-19, and P04-46-5). Nevertheless, considering all the zircons of a given sample, the ages from the cores (the $\geq 180 \mathrm{Ma}$ inherited cores excluded) and from the rims are similar within error. Thus, there is no clear evidence for distinct stages of zircon growth within the $\sim 120-160$ Ma time interval. The $\mathrm{Th} / \mathrm{U}$ ratio in the zircons is highly variable (between $<0.01$ and 0.29) and uncorrelated to the measured ages. High versus low $\mathrm{Th} / \mathrm{U}$ ratios are often considered as typical for magmatic versus metamorphic environments, respectively (e.g., Belousova et al., 2002; Rubatto, 2002). However, cases are known where metamorphic zircons also yield high Th/U values (e.g., Harley et al., 2007). In our case, 

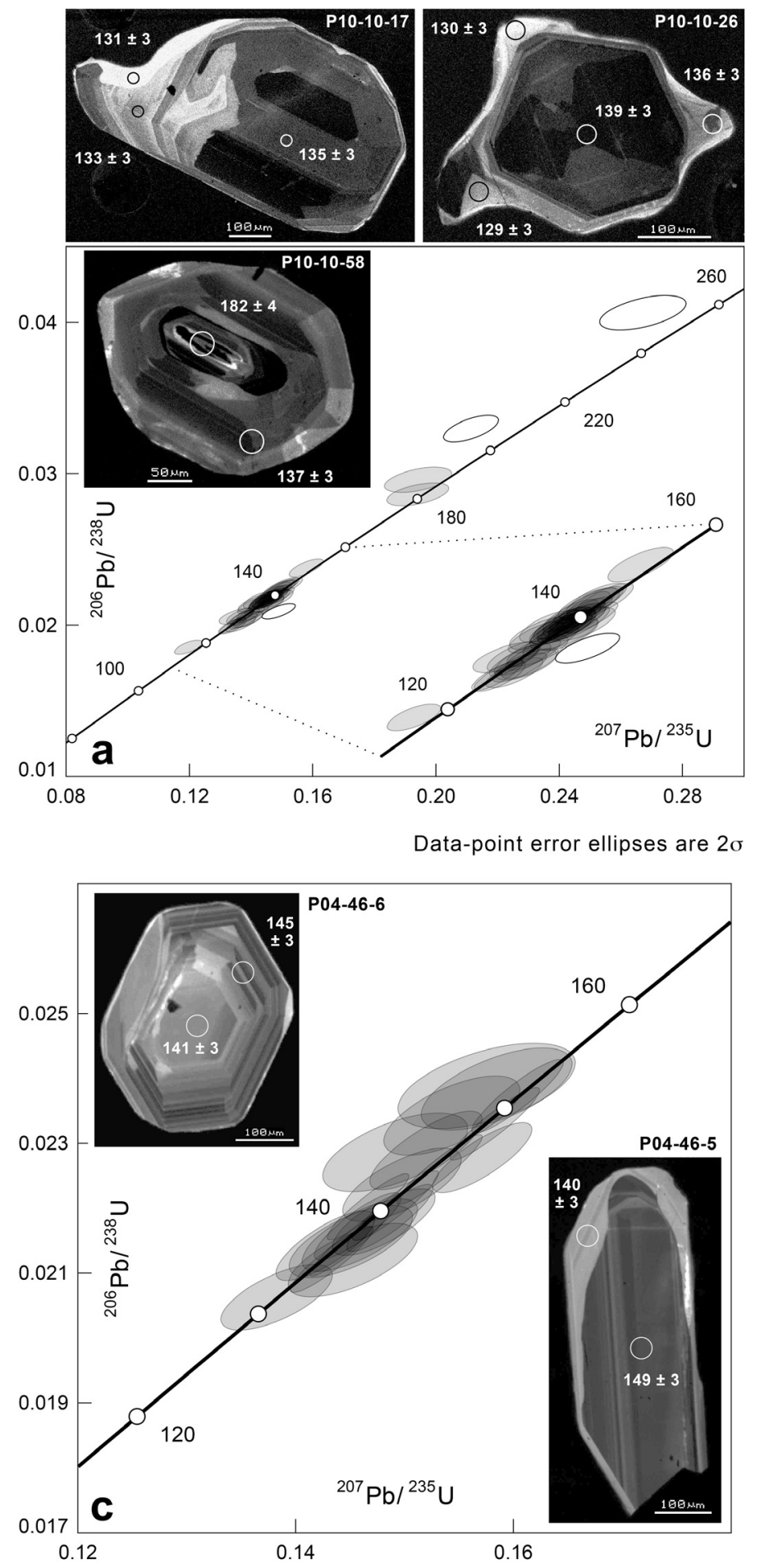
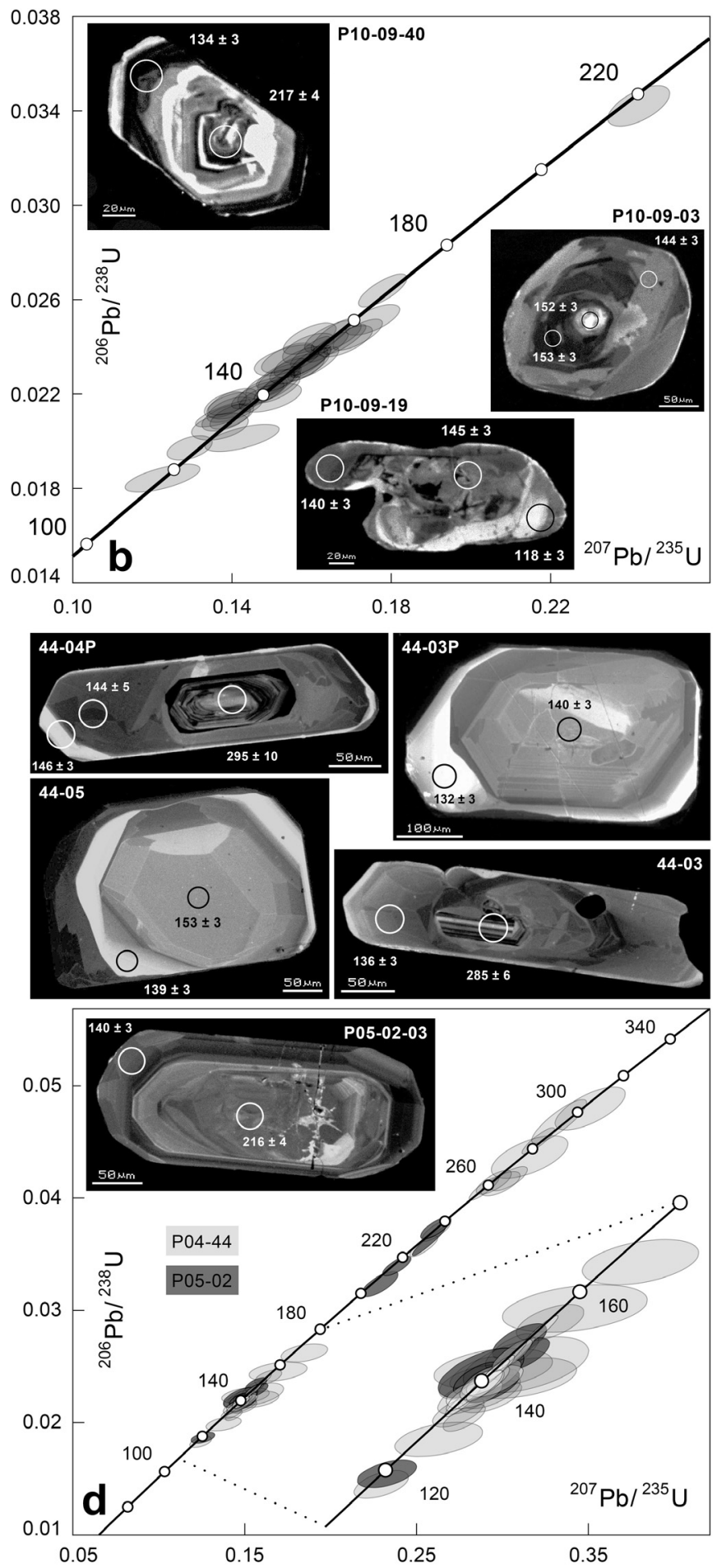

Fig. 11. CL images of representative zircon grains and Concordia diagram for zircons of samples P10-10 (a), P10-9 (b), P04-46 (c), and P04-44 and P05-2 (d). (a-c) and (d) are from part C and B of the outcrop, respectively (locations in Figs. 4, 8 and 9).

the $\mathrm{Th} / \mathrm{U}$ ratio does not seem to be useful for identifying zircon domains grown under distinct P-T conditions.

Zircons from sample P10-10 (19 grains, 49 analyses) are between 200 and $400 \mu \mathrm{m}$ in size and with $\mathrm{U}$ content between 400 and $3600 \mathrm{ppm}$. Concordant ${ }^{206} \mathrm{~Pb}^{238} \mathrm{U}$ ages range between $118 \pm 2 \mathrm{Ma}$ and $188 \pm 4 \mathrm{Ma}$ (Fig. 11a). The core of some grains yields the older concordant ages at 182 and 188 Ma together with two discordant ages suggesting even older ages. Ages obtained in the sector zoned domains range between $118 \pm 2$ and $151 \pm 3 \mathrm{Ma}$.

Zircons from sample P10-9 (19 grains, 46 analyses) are between 150 and $250 \mu \mathrm{m}$ in size and with $\mathrm{U}$ content between 200 and $3600 \mathrm{ppm}$. The grain cores have the highest $U$ contents; most of them have a metamict microstructure and yielded unreliable age results, except in one case where a ${ }^{206} \mathrm{~Pb}^{238} \mathrm{U}$ age of 

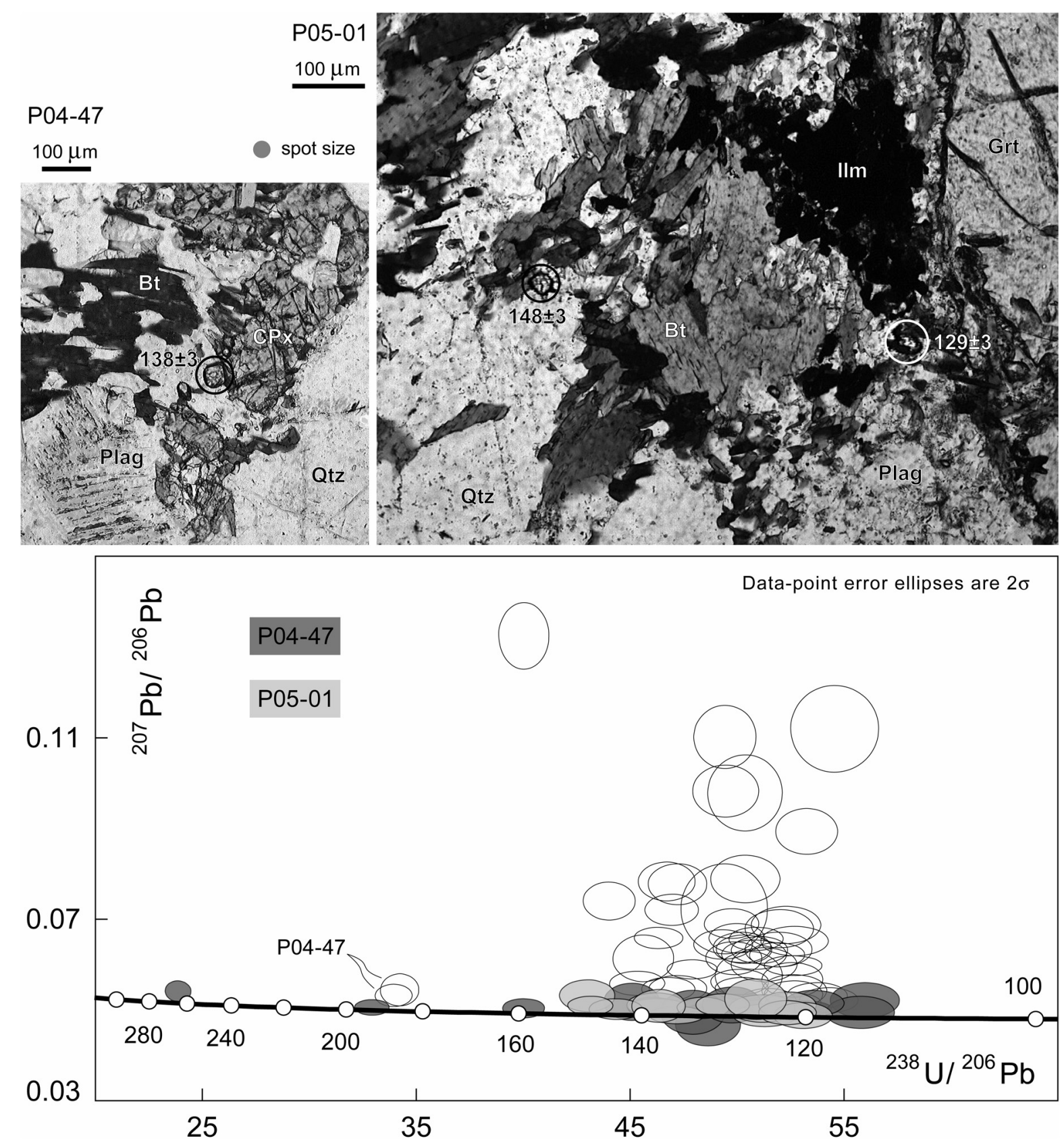

Fig. 12. Photomicrographs (with examples of zircon grains analyzed in thin section) and Tera-Wasserburg diagram for zircons of samples P04-47 and P05-1 (location in Figs. 4 and 9d). Empty ellipses correspond to discordant data and are not considered in the interpretation.

$217 \pm 4$ Ma has been obtained (Fig. 11b). The other concordant ${ }^{206} \mathrm{~Pb} /{ }^{238} \mathrm{U}$ ages range between $118 \pm 3$ and $168 \pm 4 \mathrm{Ma}$.

Zircons from sample P04-46 (11 grains, 22 analyses) are between 200 and $400 \mu \mathrm{m}$ in size and with $U$ content between 145 and $3600 \mathrm{ppm}$. No inherited core was found. Concordant ${ }^{206} \mathrm{~Pb} /{ }^{238} \mathrm{U}$ ages are between $131 \pm 3 \mathrm{Ma}$ and $151 \pm 3 \mathrm{Ma}$ (Fig. 11c).

Zircons from samples P04-47 (32 grains, 34 analyses) and P05-1 (38 grains, 40 analyses) are between 30 and $70 \mu \mathrm{m}$ in size and were analyzed in thin section. U-Pb data are reported in a Tera-Wasserburg diagram (Fig. 12). Many analyses exhibit common $\mathrm{Pb}$ contamination. Most concordant ${ }^{206} \mathrm{~Pb} /{ }^{238} \mathrm{U}$ ages range between $114 \pm 3$ and $148 \pm 4 \mathrm{Ma}$, associated with $\mathrm{Th} / \mathrm{U}$ ratios between 0.02 to 0.08 . No correlation is observed between ages and textural positions. A few older ages, up to $265 \mathrm{Ma}$, were found in $\mathrm{P} 04-47$, associated with $\mathrm{Th} / \mathrm{U}$ ratios between 0.2 and 0.6 .

We also analyzed ten monazite grains, 200 to $300 \mu \mathrm{m}$ in size, from sample P10-10 (41 analyses). A few grains display concentric or sector zoning (Fig. 13) but the majority is unzoned. Most ${ }^{206} \mathrm{~Pb} /{ }^{238} \mathrm{U}-{ }^{207} \mathrm{~Pb} /{ }^{235} \mathrm{U}$ ages are discordant because of a slight common $\mathrm{Pb}$ contamination. Because ${ }^{232} \mathrm{Th}$ is very abundant in these monazites, ${ }^{208} \mathrm{~Pb}$ originating from common $\mathrm{Pb}$ is negligible compared to radiogenic ${ }^{208} \mathrm{~Pb}$. Hence, concordant ${ }^{206} \mathrm{~Pb} /{ }^{238} \mathrm{U}_{-}{ }^{208} \mathrm{~Pb} /{ }^{232} \mathrm{Th}$ ages are considered reliable. These concordant ${ }^{206} \mathrm{~Pb} /{ }^{238} \mathrm{U}$ ages range between $116 \pm 3$ and $148 \pm 4 \mathrm{Ma}$, consistent with the 


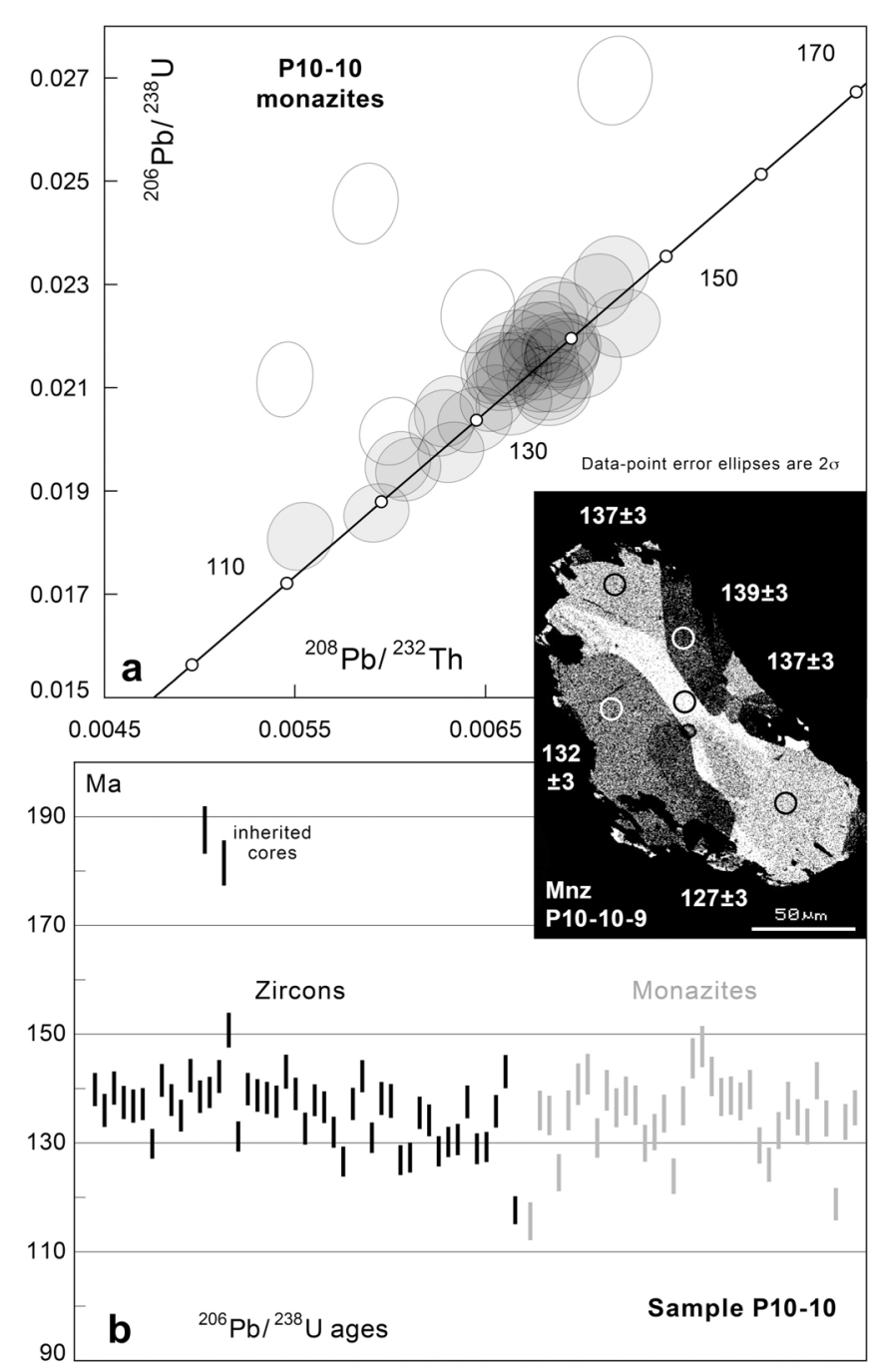

Fig. 13. (a) BSE image of one monazite grain and $\mathrm{U}-\mathrm{Th}-\mathrm{Pb}$ monazite data for sample P10-10. Empty ellipses correspond to discordant ${ }^{208} \mathrm{~Pb} /{ }^{232} \mathrm{Th}-{ }^{206} \mathrm{~Pb} /{ }^{238} \mathrm{U}$ data and are not considered in the interpretation. (b) Graph allowing comparison of the ${ }^{206} \mathrm{~Pb} /{ }^{238} \mathrm{U}$ ages $(2 \sigma)$ obtained on monazite ( $c f$. above) and on zircon ( $c f$. Fig. 11a) in this sample.

${ }^{206} \mathrm{~Pb} /{ }^{238} \mathrm{U}$ ages obtained in the zircons from the same sample (Figs. 11a and 13).

\subsection{Samples from part A of the outcrop}

We studied zircons from the pegmatoid vein P10-8 (41 grains, 68 analyses) as well as from fragments of migmatitic gneiss in contact with the vein (subsample referred to as P10-8G; 44 grains, 87 analyses). The grains mostly consist of thin elongated prismatic crystals, which is usual for zircons grown during low-temperature anatexis with high water activity (Harley et al., 2007). Two groups of zircon crystals are distinguished based on their internal structures and ages (Fig. 14).

The first group is present in both P10-8 and P10-8G and consists of composite zircons, 100 to $250 \mu \mathrm{m}$ in size, with a core surrounded by one or two rims. The core domains have ${ }^{206} \mathrm{~Pb} /{ }^{238} \mathrm{U}$ ages ranging between $305 \pm 6$ and $1844 \pm 42 \mathrm{Ma}$. Their U content is between 24 and $1157 \mathrm{ppm}$ and $\mathrm{Th} / \mathrm{U}$ ratios are between 0.04 and 1.3 , uncorrelated to the measured ages. Internal rims display oscillatory zoning, suggesting a magmatic origin. Their ${ }^{206} \mathrm{~Pb} /{ }^{238} \mathrm{U}$ ages range between $241 \pm 6$ and $307 \pm 8 \mathrm{Ma}$. Their $\mathrm{U}$ content is between 24 and $1839 \mathrm{ppm}$ and $\mathrm{Th} / \mathrm{U}$ ratios are between $<0.01$ and 1.22 , uncorrelated to the measured ages. Some of the grains of this first group further exhibit an external rim of irregular thickness, with a light homogeneous appearance on the CL images. These external rims are U-poor ( $<130 \mathrm{ppm}$ except one analysis at $2620 \mathrm{ppm})$, with $\mathrm{Th} / \mathrm{U}$ ratios between $<0.01$ and 0.05 . In a Tera-Wasserburg diagram, most related ages are discordant but define a linear trend that crosscuts the concordia at $\sim 41 \mathrm{Ma}$; in addition, one grain with a thicker external rim (P10-08-06) has yielded one concordant ${ }^{206} \mathrm{~Pb} /{ }^{238} \mathrm{U}$ age of $42 \pm 2 \mathrm{Ma}$ (Fig. 14).

The second group of crystals is present in P10-8 only and consists of metamict zircons around $150 \mu \mathrm{m}$ in size (e.g., grain $\mathrm{P} 10-08 \mathrm{~m}-01$ in Fig. 14). These grains are U-rich (1270 $19400 \mathrm{ppm})$, with $\mathrm{Th} / \mathrm{U}$ ratios between $<0.01$ and 0.11 . They yield discordant ages due to common $\mathrm{Pb}$ contamination together with $\mathrm{Pb}$ loss, a usual feature in metamict zircons. Nevertheless, reported in the Tera-Wasserburg diagram, the analyses yielding the oldest ages plot along the same trend as that defined by the external rims of the first group of crystals. These analyses can thus be considered as the least affected by $\mathrm{Pb}$ loss. Combining these data (the filled ellipses with thin contours in Fig. 14) with those of the external rims, a linear trend is defined that crosscuts the concordia at $42.7 \pm 1.4 \mathrm{Ma}(\mathrm{MSWD}=12 ; \mathrm{n}=16)$.

\subsection{Samples from part B of the outcrop}

Zircons from samples P04-44 (24 grains, 41 analyses) and P05-02 (9 grains, 11 analyses) are 200 to $400 \mu \mathrm{m}$ in size and are similar in morphology and internal structure to those analyzed in samples from the structural lens $\mathrm{C}$, although large prismatic crystals are more abundant (Fig. 11d). Some grains contain an inherited core displaying oscillatory zoning. Their $\mathrm{U}$ content is between 223 and $2274 \mathrm{ppm}$, with $\mathrm{Th} / \mathrm{U}$ ratios between $<0.01$ and 0.8 . These cores yield concordant ${ }^{206} \mathrm{~Pb} /{ }^{238} \mathrm{U}$ ages between $227 \pm 5$ and $302 \pm 10 \mathrm{Ma}$ in P04-44 and between $205 \pm 6$ and $236 \pm 5$ in P05-2. Outside the core domains, the zircons yield mid-Mesozoic ages, between $117 \pm 3 \mathrm{Ma}$ and $166 \pm 4 \mathrm{Ma}$. Their $\mathrm{U}$ content is between 78 and $1410 \mathrm{ppm}$, with $\mathrm{Th} / \mathrm{U}$ ratios between $\sim 0$ and 0.02 .

We also analyzed twenty rutile grains from sample P04-44 (39 analyses). The crystals are rod-shaped, about 200-300 $\mu \mathrm{m}$ long and $30-60 \mu \mathrm{m}$ wide. Their $\mathrm{U}$ content is between 48 and $120 \mathrm{ppm}$. Most of the U-Pb ages are discordant; nevertheless, plotted in a Tera-Wasserburg diagram, they define a linear trend that crosscuts the concordia at $\sim 39 \mathrm{Ma}$ (Fig. 15). Seven concordant ${ }^{206} \mathrm{~Pb} /{ }^{238} \mathrm{U}-{ }^{207} \mathrm{~Pb} /{ }^{235} \mathrm{U}$ ages define a concordia age of $40.4 \pm 0.6 \mathrm{Ma}$.

\section{Interpretation and discussion}

\subsection{Two partial melting events separated by a $\sim 100$ Myr interval}

Field observations document the existence of two partial melting events on the studied outcrop. As discussed at the end 

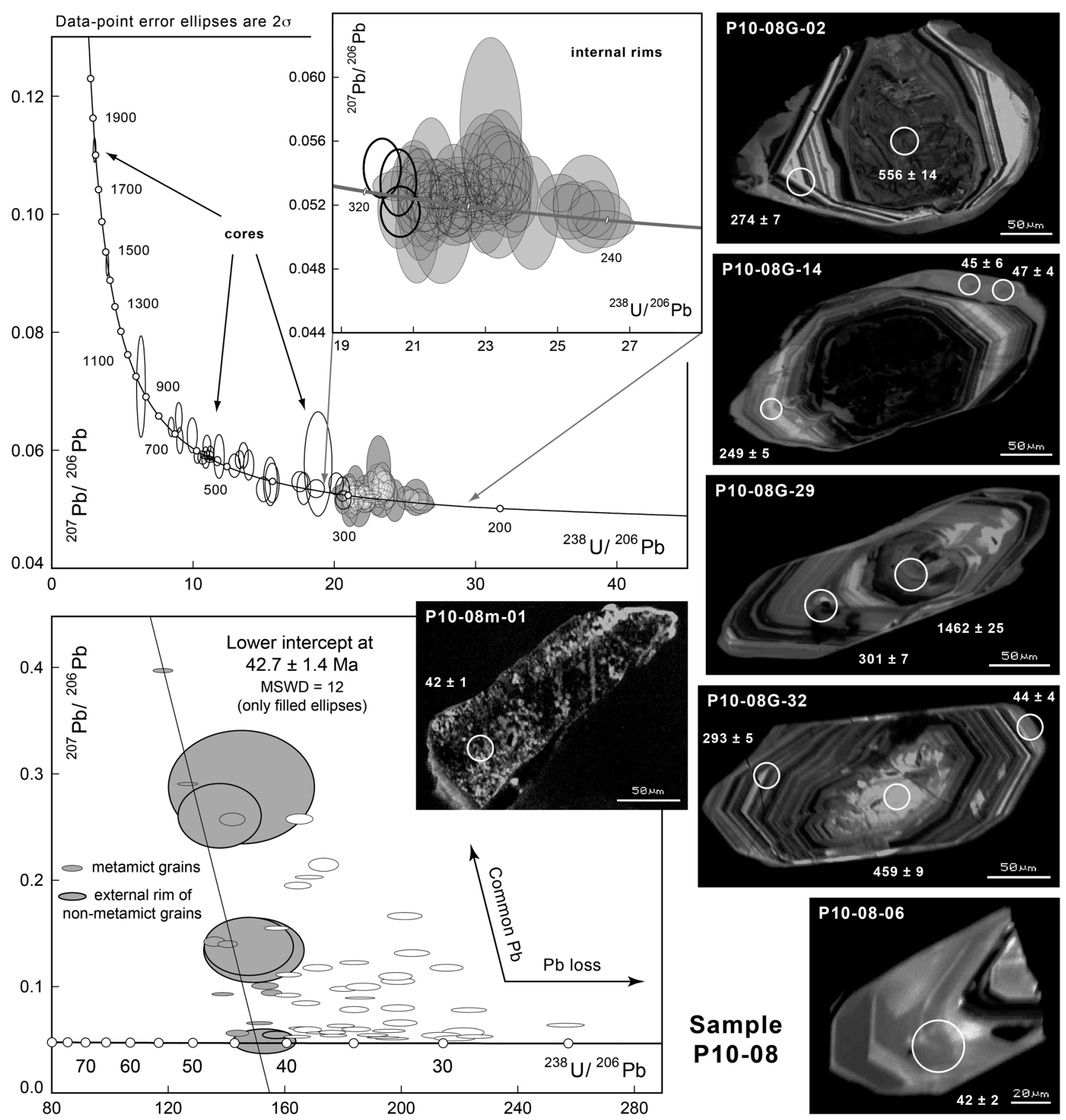

Fig. 14. CL images of representative zircon grains and Tera-Wasserburg diagrams for zircons of sample P10-8 (location in Figs. 4 and $6 \mathrm{~b}$ ). In the upper diagram, empty ellipses correspond to inherited core domains while filled ellipses correspond to internal rim domains. In the lower diagram, external rim domains are plotted together with the analyses of metamict zircons; filled ellipses correspond to data used for calculating the lower-intercept age.

of Section 4, considering the available age constraints on this outcrop (Didier et al., 2014; Liati, 2005), determining the timing of the two events required further investigations. The data presented in Section 5 document that the first event is midMesozoic $(\sim 140 \mathrm{Ma})$ and the second event is mid-Cenozoic ( 40 Ma) (Fig. 16).

The first event involved "dry" melting under high-grade conditions $\left(\geq 800^{\circ} \mathrm{C}\right)$, as confirmed by the petrological analysis presented in Supplementary material S1. The morphology and internal structure of the zircon grains yielding mid-Mesozoic ages are consistent with their growth under such conditions (Harley et al., 2007). The rare earth elements (REE) pattern of these zircons shows an almost flat distribution of the heavy REE (see Supplementary material S5), consistent with their growth in the presence of garnet in a relatively "closed" system (Rubatto, 2002). All the samples recording this event 


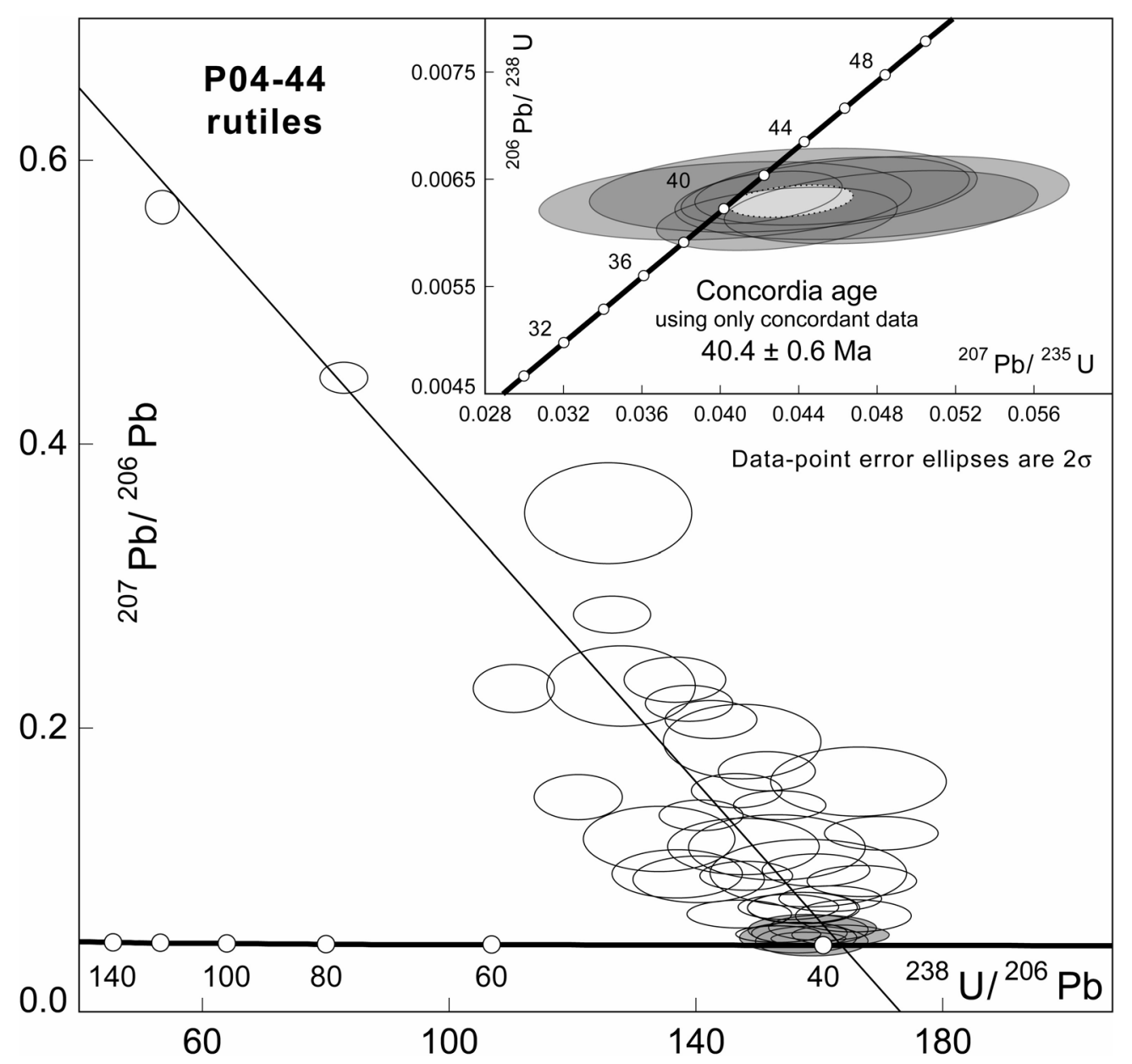

Fig. 15. U-Pb rutile dating results for sample P04-44 (location in Figs. 4 and 8). In the Tera-Wasserburg diagram, empty ellipses correspond to discordant data affected by common $\mathrm{Pb}$ contamination. In the Concordia diagram (insert), only the concordant data are reported and used for calculating the age of $40.4 \pm 0.6 \mathrm{Ma}$.

are characterized by a large spread in ages, the shortest age range spanning $20 \mathrm{Myr}$, in sample P04-46 (Fig. 11c). Zircon and monazite ages from the same sample (P10-10) display the same spread (Fig. 13). Altogether, the samples from this study yield ages scattered between $\sim 115$ and $\sim 165 \mathrm{Ma}$. A similar age scatter has been obtained in other samples from the NSZ and the CSZ (Bosse et al.,2009; Didier et al., 2014) (see Sect. 3). In the case of the Mesozoic monazites in garnet-kyanite micaschists such as sample P03-9, Didier et al. (2014) found no correlation between ages and chemical compositions, nor between ages and textural positions. In samples P10-10, P10-9 and P04-46, zircon core and zircon rim ages are similar within error. For the zircons of samples P04-47 and P05-1, analyzed in thin section, we found no correlation between ages and textural positions. Thus, no distinct events are identified within the mid-Mesozoic age range. Because the same age range $(\sim 115-165 \mathrm{Ma})$ is obtained from different mineral phases (zircon and monazite) and from different samples with far-distant locations (along the NSZ and on the CSZ), the whole age range may be geologically meaningful and may date a protracted tectono-metamorphic event. Nevertheless, this remains speculative and we think that it is safer to take the "central" age of $\sim 140 \mathrm{Ma}$ as the best estimate for the age of the first anatectic event.
The second anatectic event involved syn-kinematic waterassisted melting under lower-grade conditions (between $\sim 625^{\circ} \mathrm{C}$ and $\sim 750-800^{\circ} \mathrm{C}$ ). Two samples, P05-2 and P10-8, have been collected for the purpose of dating this event. P05-2, from a leucocratic gneiss hosting numerous syn-kinematic leucosomes (Fig. 8a), turned out to contain only few zircons. These zircons record only the first anatectic event (Fig. 11d). Both the pegmatoid vein P10-8 (Fig. 6b) and its host migmatitic gneiss $\mathrm{P} 10-8 \mathrm{G}$ contain zircons with thin rims of homogeneous appearance (Fig. 14). In addition, P10-8 contains numerous metamict zircons very rich in uranium (up to $19400 \mathrm{ppm}$ ), in line with a fluid-saturated environment formed at late stages of crystallization of a felsic magma. The REE pattern of these zircons shows a strong enrichment in heavy REE and a flat distribution of the light REE with no significant anomaly in Ce (see Supplementary material S5). This type of pattern is known from hydrothermal zircons grown during late-stage granitoid crystallization (Hoskin, 2005 ). Thus, the age of $42.7 \pm 1.4 \mathrm{Ma}$, obtained by combining the data from the metamict zircons and the thin rims of the other grains (Fig. 14), can be interpreted as the age of crystallization of the vein and, more generally, the age of the second anatectic event. The $\mathrm{U}-\mathrm{Pb}$ age of $\sim 39 \mathrm{Ma}$ obtained on 

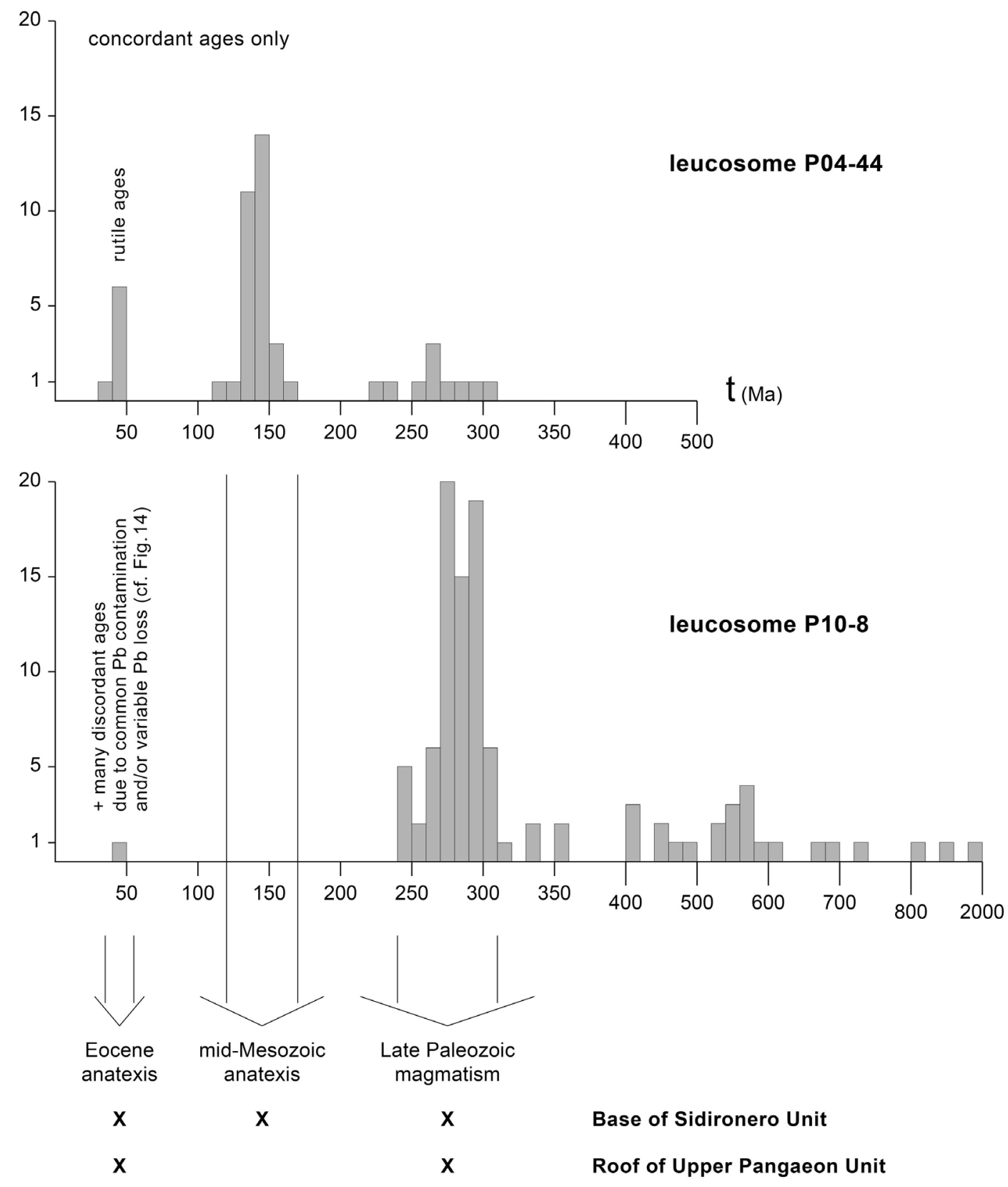

Fig. 16. Histograms of the distribution of ${ }^{206} \mathrm{~Pb} /{ }^{238} \mathrm{U}$ zircon ages (and rutile ages where indicated) in samples $\mathrm{P} 04-44$ and $\mathrm{P} 10-8$. The interpretation of these ages is shown at the bottom (see the text for details).

two zircon rims from a leucosome (Liati, 2005) indicates that anatexis was still underway at that time. The $\mathrm{U}-\mathrm{Pb}$ rutile age of $40.4 \pm 0.6 \mathrm{Ma}$ obtained on sample P04-44 (Fig. 15) probably reflects the same event. P04-44 comes from a pegmatoid leucosome with garnets in the adjacent mafic selvedges, suggesting that this leucosome does not relate to the second but to the first anatectic event, in agreement with its zircon age content (Fig. 11d). Nevertheless, top-to-SW shearing in this rock occurred at temperatures of at least $\sim 650{ }^{\circ} \mathrm{C}$ (see Sect. 4) and the adjacent gneisses also contain thin syn-kinematic leucosomes (Fig. 8a, e). Hence, there is some logic to link the rutile age of $\sim 40 \mathrm{Ma}$ to the second anatectic event (Fig. 16), even though P04-44 may not have experienced water-assisted melting during the Cenozoic due to limited fluid inflow in this stronger coarse-grained lithology.

\subsection{A major thrusting event during Eocene anatexis}

The second anatectic event is visible in parts $\mathrm{A}$ and $\mathrm{B}$ of the outcrop (Fig. 4). Some of the related leucosomes show evidence of a syn-kinematic emplacement with respect to the top-to-SW shear fabric that characterizes the NSZ (Figs. 6 and 8) (see Sect. 4). This contradicts the opinion of Nagel et al. (2011) that migmatization was strictly pre-kinematic, based on observations on the same outcrop. The second anatectic event involved water-assisted melting, which must have occurred at 


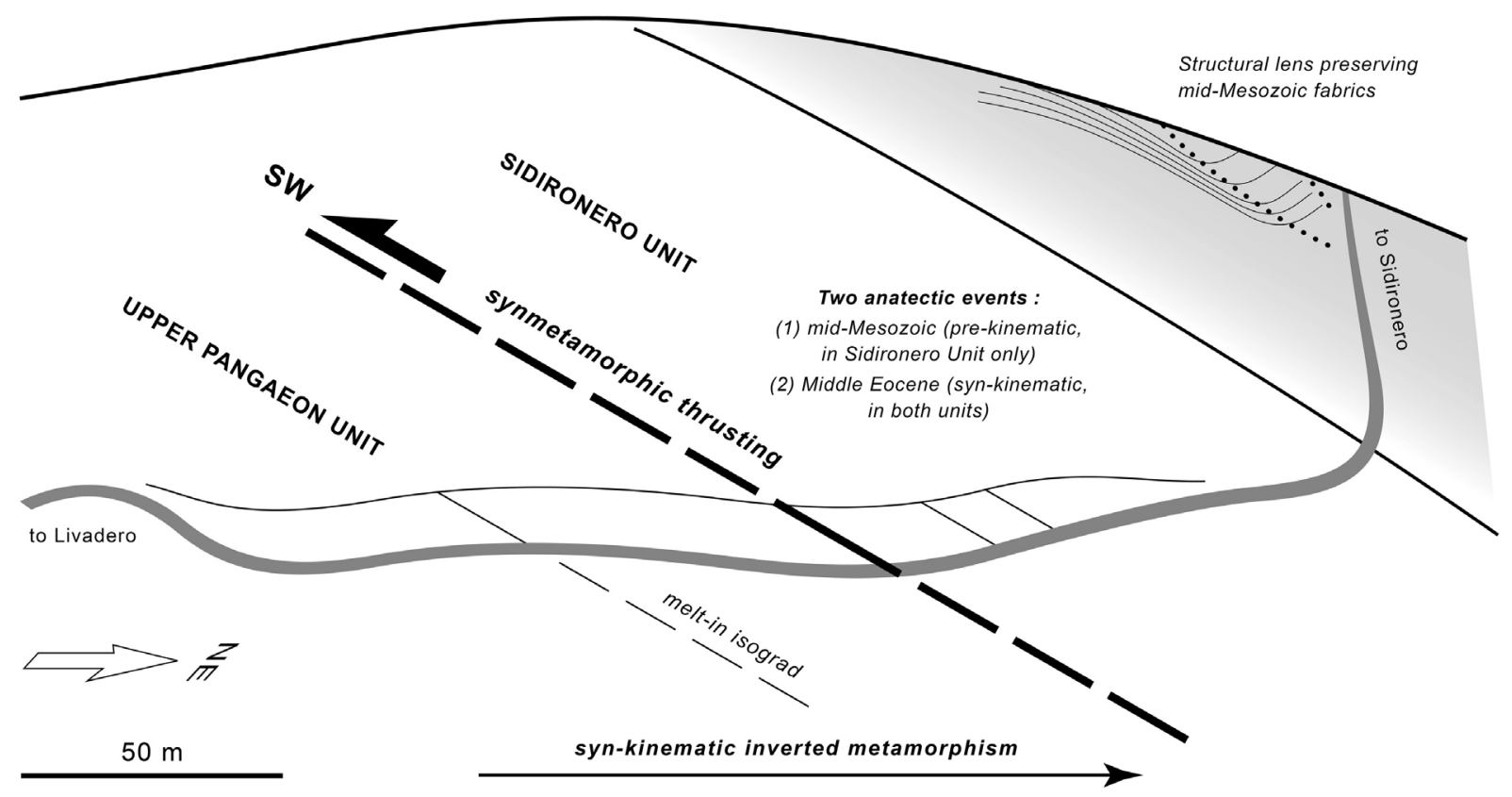

Fig. 17. Sketched oblique aerial view of the studied outcrop and its interpretation in terms of tectono-metamorphic evolution.

temperatures between $\sim 625^{\circ} \mathrm{C}$ and $\sim 750-800^{\circ} \mathrm{C}$. At lower levels of the NSZ, near the base of the UPU (Fig. 3), peak metamorphic assemblages imply lower-grade conditions, with maximum temperatures less than $625^{\circ} \mathrm{C}\left(\leq 580^{\circ} \mathrm{C}\right.$ according to Krohe and Mposkos, $2002 ; \sim 520^{\circ} \mathrm{C}$ according to Nagel et al., 2011). In line with this view, there is no sign of migmatization in the gneisses of the UPU. Thus, an inverted metamorphic sequence really exists across the NSZ, as argued by many authors since Jordan (1969) (see Sect. 3). Here we demonstrate that migmatization at higher levels of the NSZ is part of this sequence and that it developed during shearing.

On the scale of the outcrop, inverted metamorphism is suggested by the presence of non-migmatitic gneisses beneath the migmatitic gneisses of A (Fig. 4). Sample P10-8 comes from the central part of A and contains inherited Late Paleozoic (essentially Permian) magmatic zircons but is devoid of zircon domains with mid-Mesozoic ages (Figs. 14 and 16). This age pattern is typical of the PU and UPU (Turpaud and Reischmann, 2010) (see Sect. 3). All other dated samples come from higher structural levels of the outcrop (Fig. 4) and contain mid-Mesozoic zircon domains related to high-grade metamorphism. This is typical of lower levels of the SU (see Sect. 3). Hence, the contact between UPU and SU is located on the outcrop. It probably coincides with the mylonitic levels overlying A (Fig. 17). This is consistent with the midMesozoic geochronological record in sample P03-9 (Didier et al., 2014). As a result, the melt-in isograd is located in the uppermost levels of the UPU, about $30 \mathrm{~m}$ beneath the contact with the SU. Two main processes, not mutually exclusive, may account for the presence of this narrow strip of migmatites along the roof of the UPU. The strip may reflect the "hot iron" effect produced by carrying a higher-grade hangingwall (the SU) onto its footwall (the UPU) (e.g., Le Fort, 1996), a process possibly assisted by shear heating along the main fault contact (e.g., Duprat-Oualid et al., 2013). Alternatively, because the second anatectic event involved water-assisted melting, the strip may represent the width of the zone in which fluids were abundant enough to produce large amounts of melt. The location of the strip right beneath the main tectonic contact suggests that fluids may have been channelized along this contact. Thus, on the scale of the outcrop, the presence of migmatitic above non-migmatitic gneisses may reflect a gradient in fluid availability rather than a gradient in temperature.

Even so, on the scale of a section across the NSZ (Fig. 3), a field temperature gradient exists, which involves synkinematic migmatites. Regardless of the exact process(es) that led to the establishment of the inverted metamorphic sequence (see, e.g., Pitra et al., 2010, for a review), this sequence necessarily results from large-scale thrusting. The geochronological data constrain the age of migmatization at 39-43 Ma (Liati, 2005; this work). Hence, the NSZ acted as a major thrust at that time (Fig. 17). Consequently, the picture of the NSZ representing a Mesozoic or Mesozoic-Paleocene thrust (Ricou et al., 1998; Papanikolaou and Kranis, 2004; Krenn et al., 2010; Burg, 2011; Schenker et al., 2014; Brun et al., 2016) must be abandoned, an inference also supported by the complete lack of Mesozoic-Paleocene ages in the geochronological record of the PU and the UPU.

After migmatization at $\sim 39-43 \mathrm{Ma}$, the rocks started to cool down. The timing of early cooling is constrained by the U$\mathrm{Pb}$ age of $36.3 \pm 1.5 \mathrm{Ma}$ obtained on the syn-kinematic matrix monazites from sample P03-9 (Didier et al., 2014) (Fig. 7). For assessing the temperature conditions attached to this age, $\mathrm{Zr}$ in-rutile thermometry has been applied on rutile grains closely associated with the matrix monazites (Fig. 7d). The two thermometers of Watson et al. (2006) and Ferry and Watson (2007) yield a similar weighted mean temperature of $621 \pm 22^{\circ} \mathrm{C}$ (see Supplementary material S6). A temperature of $\sim 620^{\circ} \mathrm{C}$ is consistent with an interpretation of the monazites as having precipitated from fluids released during the crystallization, at solidus conditions, of the nearby anatectic 


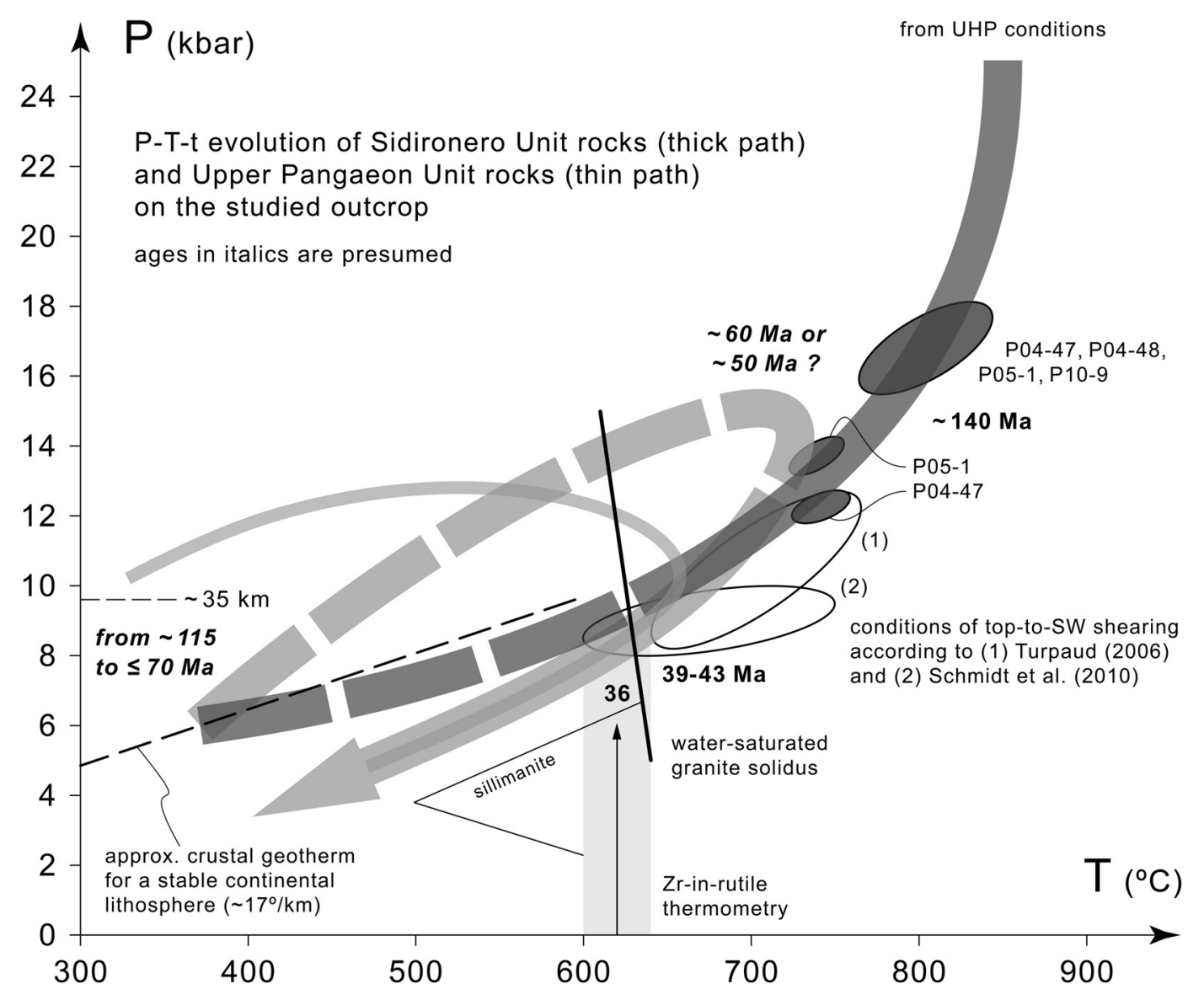

Fig. 18. Pressure-temperature diagram showing the proposed P-T-t evolution of the rocks from the SU and UPU on the studied outcrop. See the text for explanations.

melts (Didier et al., 2014). Thus, at $\sim 36 \mathrm{Ma}$ and during ongoing shearing, the studied outcrop was at temperatures still above the peak temperatures experienced by the rocks at the base of the UPU. This attests for the persistence of inverted metamorphism at that time, documenting ongoing thrusting at $\sim 36 \mathrm{Ma}$. On the basis of additional structural and ${ }^{40} \mathrm{Ar} /{ }^{39} \mathrm{Ar}$ data not presented here, we believe that the NSZ remained active as a thrust until $\sim 33 \mathrm{Ma}$ (Gautier et al., 2010). At variance with Nagel et al. (2011), our opinion is that the NSZ never operated as a normal-sense shear zone. Even the latest increments of top-to-S/SW shearing, manifested in $100 \mathrm{~m}$ scale shallow-dipping shear planes (e.g., at the right end of the cross-section in Fig. 3), can be interpreted as reflecting thrusting. Regardless, even if an age of $36 \mathrm{Ma}$ is conservatively taken for the end of thrusting along the NSZ, it appears that the RMC cannot have been in a stage of post-orogenic whole-crust extension as early as $40 \mathrm{Ma}$ or more (e.g., Kilias et al., 1999; Brun and Sokoutis, 2007; Jolivet and Brun, 2010; Burg, 2011; van Hinsbergen and Schmid, 2012). For the purpose of this paper, the important point is that, $\sim 100 \mathrm{Myr}$ after the first anatectic event (a time laps that encompasses the period from $\sim 115$ to $\sim 70 \mathrm{Ma}$ without geochronological record on the regional scale, see Sect. 2.1), the second anatectic event did not occur in a context of delamination-driven extension (Jolivet and Brun, 2010; Burg, 2011; Marchev et al., 2013; Brun et al., 2016) but in a context of crustal-scale thrusting. This attests for polycyclic orogeny in the RMC during Alpine times.
Importantly, this conclusion is independent of whether or not distinct episodes of eclogitization occurred over the same period (see Sect. 2.1).

\subsection{Polycyclic orogeny and two-loop P-T-t path of the Sidironero Unit}

Polycyclic Alpine orogeny implies that some rocks underwent at least two metamorphic cycles during MesoCenozoic times. On the studied outcrop, the rocks of the SU did so. In contrast, those of the UPU recorded exclusively the Eocene event (Figs. 16 and 17). This is best explained with the hypothesis that the UPU and PU were not involved in the orogen before the Cenozoic, in agreement with several authors (Argyriadis and Fourquin, 1987; Dinter, 1998; Krohe and Mposkos, 2002; Jahn-Awe et al., 2010; Froitzheim et al., 2014). In the following, we discuss the possible shape of the PT-t path followed by the SU rocks. This path may be compared with the two-loop P-T-t paths inferred from equivalent rocks by Mposkos et al. (2010) and Wawrzenitz et al. (2015).

The proposed P-T-t evolution is reported in Figure 18. Only a late part of the mid-Mesozoic P-T path is shown. Before, the rocks experienced UHP conditions (e.g., Mposkos and Kostopoulos, 2001; Schmidt et al., 2010). The age of UHP metamorphism is debated, but, considering the variety of opinions in the literature, it should have occurred at some time 
between $\sim 200$ and $\sim 150 \mathrm{Ma}$ (e.g., Liati et al., 2011; Nagel et al., 2011). Petrik et al. (2016) have recently proposed that the UHP rocks underwent polycyclic orogeny within the time laps between $\sim 200$ and $\sim 160 \mathrm{Ma}$, a hypothesis that we do not discuss here. Our Mesozoic P-T path starts in high-pressure granulite facies conditions, at $\sim 16-18 \mathrm{kbar} / \sim 800^{\circ} \mathrm{C}$, and evolves toward lower-grade conditions $\left(\sim 13 \mathrm{kbar} / \sim 750^{\circ} \mathrm{C}\right)$. These P-T conditions are deduced from the petrological analysis (see Supplementary Material S1) of samples from the structural lens $\mathrm{C}$ which we interpret as preserving midMesozoic mineralogical assemblages and fabrics (Fig. 17). As discussed in Section 6.1, a wide range of ages $(\sim 115-165 \mathrm{Ma})$ has been obtained through $\mathrm{U}-\mathrm{Pb}$ zircon and monazite dating of these rocks, but no distinct event could be identified within this range. Thus, the "central" age of $\sim 140 \mathrm{Ma}$ is considered as the best age estimate for the above P-T conditions. The period between $\sim 115$ and $\sim 70 \mathrm{Ma}$ is characterized by a gap in the geochronological record on the scale of the RMC, the Eastern Rhodope excluded (see Sect. 2.1). We interpret this gap as reflecting a period of relative tectonic quiescence. Its long duration makes it likely that the earlier orogen was eventually erased and the lithosphere returned to a stable geotherm. Hence, the end of the mid-Mesozoic P-T path should be sited at some point along this geotherm. In Figure 18, we have taken $17^{\circ} / \mathrm{km}$ for the mean geothermal gradient in a stable continental crust, which yields $600^{\circ} \mathrm{C}$ at the base of a crust $35 \mathrm{~km}$ thick. During the period from $\geq 100$ to $\sim 70 \mathrm{Ma}$, the RMC was in a supra-subduction setting (except possibly the PU and UPU; e.g., Froitzheim et al., 2014) and evolved from fore-arc to "near-arc" conditions as a result of the southward migration of arc magmatism in the Srednogorie domain north of the RMC (e.g., Gallhofer et al., 2015). Consequently, the geothermal gradient within the RMC may have progressively increased, but no attempt is made to display this feature in Figure 18 . The end point of the first P-T loop is tentatively set at $6 \mathrm{kbar} / 370^{\circ} \mathrm{C}$, but this point could be elsewhere along the stable geotherm. The only available constraint is that the depth at which the rocks were lying at $\sim 80 \mathrm{Ma}$ was probably not greater than $35 \mathrm{~km}$ because the earlier orogen was presumably destroyed and the crust had probably returned to a normal thickness. Taking a mean density of 2.8 for the continental crust, this yields a pressure of $\sim 9.5 \mathrm{kbar}$ (and a temperature of $600{ }^{\circ} \mathrm{C}$, using a gradient of $17^{\circ} / \mathrm{km}$ ) for the greatest possible conditions at the end of the first P-T loop.

The P-T loop associated with renewed orogeny during the Cenozoic should start from the end point of the first loop. The early part of this second loop, shown with a dashed line, is indirectly constrained by the P-T path of the UPU (Fig. 18). The UPU rocks experienced peak pressure conditions of 911 kbar according to Krohe and Mposkos (2002) and Nagel et al. (2011). Our own data (not presented here) on garnetbearing micaschists from lower levels of the UPU south of Livadero (Fig. 3) point to peak pressures of $\sim 12-13 \mathrm{kbar}$ at $\sim 450^{\circ} \mathrm{C}$. Syn-kinematic inverted metamorphism implies that the SU was thrust onto the UPU. Therefore, at some time during the Cenozoic, the SU rocks were located at depths at least as great as the maximum depth experienced by the UPU rocks. This implies that the SU rocks experienced peak pressures of at least 12-13 kbar. As discussed above, they were probably at pressures less than $9.5 \mathrm{kbar}$ at the end of the first loop. Hence, the SU rocks were buried, presumably through underthrusting, during early stages of the Cenozoic orogeny. Cenozoic peak pressures of at least $12-13 \mathrm{kbar}$ for the SU rocks on the DSCS differ significantly from the Cenozoic peak pressures of 6.0-7.5 kbar proposed by Wawrzenitz et al. (2015) for seemingly equivalent rocks at Thermes (Fig. 1). The great distance between the two locations $(\sim 65 \mathrm{~km})$ makes it possible that the related rocks occupy the same position in the metamorphic pile but underwent distinct P-T evolutions. This is illustrated by the fact that the P-T conditions of $6.0-7.5 \mathrm{kbar} /$ $690{ }^{\circ} \mathrm{C}$ determined by Wawrzenitz et al. (2015) fall into the stability field of sillimanite whereas our P-T path should not enter this field ( $c f$.Turpaud, 2006; Schmidt et al., 2010; Didier et al., 2014). In addition, the above P-T estimate at Thermes may not coincide with the peak pressure conditions experienced by these rocks during the Cenozoic. In Figure 18, we tentatively set the Cenozoic peak P-T conditions of the SU at $\sim 15 \mathrm{kbar} / 725^{\circ} \mathrm{C}$. Such values are compatible with the possible development of eclogite facies metamorphism during the early Cenozoic (see Sect. 2.1 and below).

The age of the onset of the second P-T loop is poorly constrained. Judging from the $\sim 115$ to $\sim 70 \mathrm{Ma}$ "geochronological gap" on the regional scale, renewed underthrusting of the SU rocks is unlikely to have started before $70 \mathrm{Ma}$. From $\sim 90$ to $\sim 78 \mathrm{Ma}$, syn-kinematic plutons associated with the Srednogorie magmatic arc were emplaced along the Maritsa Shear Zone, a major NW-SE strike-slip shear zone forming the northern boundary of the RMC (e.g., Georgiev et al., 2009; Naydenov et al., 2013; Gallhofer et al., 2015). At the northwestern tip of the RMC, top-to-SE oblique thrusting within higher levels of the metamorphic pile has recently been dated at $\sim 76 \mathrm{Ma}$ (Gorinova et al., 2015). The location and kinematics of this deformation suggest that it reflects the transition from an older strike-slip regime along the northern margin of the RMC to a younger orogenic regime that generated top-to-SW thrusts and reached a climax during the Cenozoic.

For the age of the metamorphic peak of the SU, we suggest either $\sim 50 \mathrm{Ma}$ or $\sim 60 \mathrm{Ma}$ (Fig. 18). The former is consistent with the $\mathrm{U}-\mathrm{Pb}$ age of $51 \pm 1 \mathrm{Ma}$ obtained on zircon rims of an amphibolitized eclogite on the studied outcrop, interpreted as dating HP conditions (Liati, 2005). An age of $\sim 60 \mathrm{Ma}$ would be more in line with the U-Th-Pb monazite age of $55 \pm 1 \mathrm{Ma}$ obtained by Wawrzenitz et al. (2015) at Thermes, interpreted as dating the P-T conditions of $6.0-7.5 \mathrm{kbar} / 690^{\circ} \mathrm{C}$. If, as suggested above, these $\mathrm{P}-\mathrm{T}$ conditions reflect retrogression rather than the metamorphic peak, then the peak occurred before $55 \mathrm{Ma}$. At Xanthi (Fig. 1), Bosse et al. (2009) have documented anatexis at lower levels of the SU at $\sim 48-53 \mathrm{Ma}$ (see Sect. 2.2). Thus, it may be proposed that the U-Pb age of 51 Ma obtained by Liati (2005) reflects post-HP rather than HP metamorphism. Garnet amphibolites that possibly represent former eclogites are present in the structural lens $\mathrm{C}$ (see Sect. 4). Consequently, one may suspect that eclogite facies metamorphism occurred exclusively before $\sim 140 \mathrm{Ma}$. However, it is safer not to conclude on this issue for the two following reasons. First, the fact that Liati's retrogressed eclogite has a well-expressed Eocene $\mathrm{U}-\mathrm{Pb}$ record suggests that this sample was not part of the lens C. A rock from outside the lens could have recorded Cenozoic HP metamorphism. Second, the tectono-metamorphic evolution might have been diachronous along the strike of the NSZ so that, at 50 Ma, HP 
metamorphism in the west (along the DSCS) could have been synchronous with post-HP metamorphism in the east (XanthiThermes section).

After having experienced peak pressures of at least 12$13 \mathrm{kbar}$, the SU recorded syn-kinematic water-assisted melting at pressures constrained by the P-T conditions at which top-toSW shearing occurred in the garnet-kyanite metapelitic inliers, between 8 and $12 \mathrm{kbar}$ (Turpaud, 2006; Schmidt et al., 2010) (Fig. 18). Hence, "wet" melting occurred during exhumation of the SU. We interpret both melting (at $\sim 40 \mathrm{Ma}$, see Sect. 6.1 ) and exhumation as being a consequence of contemporaneous underthrusting of the UPU and PU. Burial and prograde metamorphism of the PU/UPU rocks is the most obvious way to have generated the fluids needed to account for advanced water-assisted melting in the SU and along the roof of the UPU (see Sect. 6.2). Similarly, prograde burial of the Lesser Himalayan Series along the Main Central Thrust supplied fluids that assisted widespread melting of the High Himalayan Crystallines (e.g., Le Fort, 1996). In the area of Xanthi, the Falakron marbles form the immediate footwall of the NSZ (Fig. 1). As a consequence, carbonic fluids impregnated lower levels of the SU and led to chemical disturbance of monazite grains under greenschist facies conditions, at $\sim 33 \mathrm{Ma}$ (Bosse et al., 2009). In addition, underthrusting of the UPU and PU lifted the SU rock pile, which became able to spread. Gravitational spreading is manifested by pervasive WNW-ESE stretching in the middle and higher levels of the SU (Fig. 3). North of Xanthi, equivalent levels are capped by an extensional detachment with top-to-WNW kinematics (Gautier et al., 2001). WNW-ESE stretching was active at or after $\sim 45 \mathrm{Ma}$ as indicated by one U-Pb zircon age yielded by a synfolial quartz vein (Liati and Gebauer, 1999). This age stands between the $\sim 48-53 \mathrm{Ma}$ age range obtained on synkinematic pegmatite veins from underlying levels of the SU embedded in the NSZ and the $\sim 33-36 \mathrm{Ma}$ age range determined for later shear increments under greenschist facies conditions (Bosse et al., 2009; Gautier et al., 2010). Thus, topto-SW thrusting along the NSZ and WNW-ESE stretching at higher structural levels were contemporaneous. Spreading proceeded at almost right angle to the direction of convergence, like in some parts of the Himalaya (e.g., Gapais et al., 1992; Le Fort, 1996) and in the Central Alps (e.g., Merle et al., 1989; Mancktelow, 1992; Steck and Hunziker, 1994). Synthrusting extensional shearing also occurred during the Late Eocene in the hangingwall of the CSZ (Fig. 1) (Gerdjikov et al., 2010). In that case, the directions of thrusting and extension were close, with opposite kinematics. Syn-thrusting extensional spreading of the main part of the SU explains the coeval exhumation of lower levels of the unit involved in the NSZ. It probably also accounts for the fact that the UPU rocks (i.e., the footwall of the main thrust) started to be exhumed while thrusting went on (Fig. 18). For this to occur, it simply needs the exhumation rate accommodated by spreading and/or erosion to be greater than the burial rate accommodated by thrusting, a likely situation at late stages of a crustal thrust system. In the Himalaya, the Main Central Thrust provides an example of this case (e.g., Brunel and Andrieux, 1980; Daniel et al., 2003). Thus, at variance with Nagel et al. (2011), we reject syn-kinematic exhumation of the UPU as an evidence for an extensional origin of the NSZ top-to-SW shear fabric. Synthrusting spreading of the hangingwall unit led to fast exhumation of the thrust zone, which likely explains why the inverted metamorphic sequence has been preserved instead of being erased during post-thickening thermal relaxation (e.g., Pitra et al., 2010).

On the studied outcrop, the P-T paths of the SU and the UPU merged during water-assisted melting, at $\sim 39-43 \mathrm{Ma}$ (Figs. 17 and 18). At $\sim 36 \mathrm{Ma}$, the temperature conditions were around $620^{\circ} \mathrm{C}$, a stage of the P-T path recorded by monazites precipitated from fluids produced by the crystallization of the anatectic melts (Didier et al., 2014). Further exhumation and cooling brought the rocks to greenschist facies conditions. This stage did not produce any significant shear fabric on the outcrop. In contrast, greenschist facies mylonites with top-toSW kinematics are present on other outcrops of lower levels of the SU along the strike of the NSZ (e.g., Kilias and Mountrakis, 1990; Gautier et al., 2010). In our view, these mylonites reflect ongoing thrusting until $33 \mathrm{Ma}$. At Xanthi, shearing along the NSZ vanished before the emplacement of the 30 Ma old Xanthi Pluton (e.g., Meyer, 1968; Liati, 1986).

\section{Conclusions}

On the studied outcrop, which exposes the tectonic contact juxtaposing SU onto UPU rocks, two partial melting events of Alpine age have been identified. The first event is restricted to the SU and is pre-kinematic with respect to the top-to-SW shear fabric of the NSZ. This event is dated at $\sim 140 \mathrm{Ma}$ and is part of a mid-Mesozoic P-T loop that went through UHP, then high-pressure granulite facies conditions. The second event is observed both in the SU and along the roof of the UPU and is syn-kinematic with respect to the NSZ. This event is dated at $\sim 40 \mathrm{Ma}$ and involved water-assisted melting. Our results indicate that syn-kinematic migmatization is part of the inverted metamorphic sequence that is usually reported from the NSZ, which demonstrates that the NSZ acted as a major synmetamorphic thrust during the Middle Eocene. The time laps of $\sim 100 \mathrm{Myr}$ between the two anatectic events encompasses the period from $\sim 115$ to $\sim 70 \mathrm{Ma}$ characterized by a gap in the geochronological record on the scale of the RMC (the Eastern Rhodope excluded). This $\sim 45 \mathrm{Myr}$ gap likely reflects a period of relative tectonic quiescence between the mid-Mesozoic orogen and the (Maastrichtian)-Cenozoic one, attesting for polycyclic Alpine orogeny in the RMC. Unlike assumed in some recent geodynamic scenarios, the Alpine evolution of the RMC did not consist of a single orogenic cycle of Mesozoic age followed by Cenozoic postorogenic extension triggered by mantle delamination. The data from the studied outcrop show that synmetamorphic thrusting was still active at $\sim 36 \mathrm{Ma}$. Hence, the RMC cannot have been in a stage of whole-crust core complex-type extension as early as $40 \mathrm{Ma}$ or more.

Polycyclic Alpine orogeny has resulted in a two-loop P-T-t path for the SU rocks. In contrast, the UPU rocks followed a single P-T loop because the PU and UPU were not involved in the orogen until the Cenozoic, at which time they became underthrust along the NSZ. The Cenozoic P-T paths of the SU and UPU merged while both units were being exhumed, a feature attributed to syn-thrusting extensional spreading of the main mass of the SU above the NSZ. Fast exhumation of the thrust zone likely explains why the inverted metamorphic 
sequence has been preserved instead of being erased during post-thickening thermal relaxation.

\section{Supplementary Material}

S1 Petrology of samples from the structural lens C.

S2 Microprobe analyses on minerals from the lens C.

S3 Analytical procedures for zircon, rutile and monazite dating.

S4 LA-ICPMS analyses.

S5 REE patterns of zircons from selected samples.

S6 Zr-in-rutile thermometry of sample P03-9.

The Supplementary Material is available at https://www.bsgf. fr/10.1051/bsgf/2017195/olm.

Acknowledgements. Nicole Wawrzenitz and Bernhard Grasemann are thanked for their constructive reviews. P.G. also thanks Dimitrios Sokoutis, Richard Moriceau, Dimitrios Kostopoulos and Philippe Turpaud for their contribution at early stages of this study.

\section{References}

Argyriadis I, Fourquin C. 1987. La structure du complexe de nappes rhodopien en Grèce: une fenêtre hellénique africaine sous les Balkans. Comptes Rendus de l'Académie des Sciences, Paris 305: 727-732.

Barr SR, Temperley S, Tarney J. 1999. Lateral growth of the continental crust through deep level subduction-accretion: a reevaluation of central Greek Rhodope. Lithos 46: 69-94.

Belousova EA, Griffin WL, O'Reilly SY, Fisher NI. 2002. Igneous zircon: trace element composition as an indicator of source rock type. Contributions to Mineralogy and Petrology 143: 602-622.

Birk F. 1970. Zur Geologie und Petrographie des östlichen Bos-DagMassivs bei Drama in Griechisch-Mazedonien. Beihefte zum Geologischen Jahrbuch 88: 5-42.

Bosse V, Boulvais P, Gautier P, Tiepolo M, Ruffet G, Devidal JL, et al. 2009. Fluid-induced disturbance of the monazite $\mathrm{Th}-\mathrm{Pb}$ chronometer: in situ dating and element mapping in pegmatites from the Rhodope (Greece, Bulgaria). Chemical Geology 261: 286-302.

Brun JP, Sokoutis D. 2007. Kinematics of the Southern Rhodope Core Complex (North Greece). International Journal of Earth Sciences 96: 1079-1099.

Brun JP, Faccenna C, Gueydan F, Sokoutis D, Philippon M, Kydonakis K, et al. 2016. The two-stage Aegean extension, from localized to distributed, a result of slab rollback acceleration. Canadian Journal of Earth Sciences 53: 1142-1157.

Brunel M, Andrieux J. 1980. Sur un modèle tectonique explicatif du métamorphisme «inverse» himalayen. Comptes Rendus de l'Académie des Sciences, Paris 291: 609-612.

Burg JP. 2011. Rhodope: from Mesozoic convergence to Cenozoic extension, review of petro-structural data in the geochronological frame. Journal of the Virtual Explorer 39: 1. DOI: 10.3809/ jvirtex.2011.00270.

Burg JP, Ricou LE, Ivanov Z, Godfriaux I, Dimov D, Klain L. 1996. Syn-metamorphic nappe complex in the Rhodope Massif: structure and kinematics. Terra Nova 8: 6-15.

Collings D, Savov I, Maneiro K, Baxter E, Harvey J, Dimitrov I. 2016. Late Cretaceous UHP metamorphism recorded in kyanitegarnet schists from the Central Rhodope Mountains, Bulgaria. Lithos 246-247: 165-181.
Daniel CG, Hollister LS, Parrish RR, Grujic D. 2003. Exhumation of the Main Central Thrust from lower crustal depths, Eastern Bhutan Himalaya. Journal of Metamorphic Geology 21: 317-334.

Didier A, Bosse V, Cherneva Z, Gautier P, Georgieva M, Paquette JL, et al. 2014. Syn-deformation fluid-assisted growth of monazite during renewed high-grade metamorphism in metapelites of the Central Rhodope (Bulgaria, Greece). Chemical Geology 381: 206-222.

Dimadis E, Zachos S. 1986. Geological map of the Greek Rhodope on the scale 1:200.000. Athens (Xanthi branch): Institute of Geology and Mineral Exploration.

Dinter DA. 1998. Late Cenozoic extension of the Alpine collisional orogen, northeastern Greece: Origin of the north Aegean basin. Geological Society of America Bulletin 110: 1208-1230.

Duprat-Oualid S, Yamato P, Pitra P. 2013. Major role of shear heating in intracontinental inverted metamorphism: inference from a thermo-kinematic parametric study. Tectonophysics 608: 812-831.

Ebadi A, Johannes W. 1991. Beginning of melting and composition of first melts in the system Qz-Ab-Or- $\mathrm{H}_{2} \mathrm{O}-\mathrm{CO}_{2}$. Contributions to Mineralogy and Petrology 106: 286-295.

Ferry JM, Watson EB. 2007. New thermodynamic models and revised calibrations for the Ti-in-zircon and $\mathrm{Zr}$-in-rutile thermometers. Contributions to Mineralogy and Petrology 154: 429-437.

Froitzheim N, Jahn-Awe S, Frei D, Wainwright AN, Mass R, Georgiev N, et al. 2014. Age and composition of meta-ophiolite from the Rhodope Middle Allochton (Satovcha, Bulgaria): a test for the maximum-allochtony hypothesis of the Hellenides. Tectonics 32. DOI: 10.1002/2014TC003526.

Gallhofer D, von Quadt A, Peytcheva I, Schmid SM, Heinrich CA. 2015. Tectonic, magmatic, and metallogenic evolution of the Late Cretaceous arc in the Carpathian-Balkan orogen. Tectonics 34: 1813-1836. DOI: 10.1002/2015TC003834.

Gapais D, Pêcher A, Gilbert E, Ballèvre M. 1992. Synconvergence spreading of the Higher Himalaya Crystalline in Ladakh. Tectonics 11: 1045-1056.

Gardien V, Thompson AB, Grujic D, Ulmer P. 1995. Experimental melting of biotite + plagioclase + quartz \pm muscovite assemblages and implications for crustal melting. Journal of Geophysical Research 100: 15581-15591.

Gautier P, Moriceau R, Kostopoulos D, Sokoutis D, Monié P, Van den Driessche J. 2001. Alpine thrusting versus late Alpine extension in the northern Aegean: an evaluation of the ductile record in the Rhodope massif. Geologica Balcanica 31: 104-107.

Gautier P, Gerdjikov I, Ruffet G, Bosse V, Cherneva Z, Pitra P, et al. 2010. Persistent synmetamorphic thrusting in the Rhodope until 33 Ma: evidence from the Nestos Shear Zone and implications for Aegean geodynamics. In: 19th Congress of the Carpathian-Balkan Geological Association, Thessaloniki, Greece, Geologica Balcanica, Vol. 39, pp. 122-123.

Georgiev N, Henry B, Jordanova N, Froitzheim N, Jordanova D, Ivanov Z, et al. 2009. The emplacement mode of Upper Cretaceous plutons from the southwestern part of the Sredna Gora Zone (Bulgaria): structural and AMS study. Geologica Carpathica 60: 15-33.

Gerdjikov I, Gautier P, Cherneva Z, Bosse V, Ruffet G. 2010. Late Eocene synmetamorphic thrusting and syn-orogenic extension across the metamorphic pile of the Bulgarian Central Rhodope. In: 19th Congress of the Carpathian-Balkan Geological Association, Thessaloniki, Greece, Geologica Balcanica, Vol. 39, pp. 132-133. Gorinova T, Georgiev N, Cherneva Z, Grozdev V. 2015. Kinematics and age of thrusting of the Upper onto the Middle Allochton of the Rhodope Metamorphic Complex: an example from NW Rila Mt., 
Bulgaria. In: Proceedings of the Bulgarian Geological Society Annual Conference, Sofia, pp. 93-94.

Grasemann B, Stüwe K, Vannay JC. 2003. Sense and non-sense of shear in flanking structures. Journal of Structural Geology 25: 19-34.

Harley SL, Kelly NM, Möller A. 2007. Zircon behaviour and the thermal histories of mountain chains. Elements 3: 25-30.

Hoskin PWO. 2005. Trace-element composition of hydrothermal zircon and the alteration of Hadean zircon from the Jack Hills, Australia. Geochimica et Cosmochimica Acta 69: 637-648.

Hudleston PJ. 1989. The association of folds and veins in shear zones. Journal of Structural Geology 11: 949-957.

Ivanov Z, Dimov D, Dobrev S, Kolkovski B, Sarov S. 2000. Structure, Alpine evolution and mineralizations of the Central Rhodopes area (South Bulgaria). Guide to excursion B, ABCDGEODE Workshop, Borovets, Bulgaria, "St. Kliment Ohridski" University Press, Sofia.

Jahn-Awe S, Froitzheim N, Nagel TJ, Frei D, Georgiev N, Pleuger J. 2010. Structural and geochronological evidence for Paleogene thrusting in the western Rhodopes, SW Bulgaria: elements for a new tectonic model of the Rhodope Metamorphic Province. Tectonics 29: TC3008. DOI: 10.1029/2009TC002558.

Jolivet L, Brun JP. 2010. Cenozoic geodynamic evolution of the Aegean. International Journal of Earth Sciences 99: 109-138.

Jordan H. 1969. Geologie und Petrographie im Zentralteil des Bos Dag (Drama, Griechisch-Makedonien). Geotektonische Forschungen 31: 50-85.

Kilias A, Mountrakis D. 1990. Kinematics of the crystalline sequences in the western Rhodope Massif. Geologica Rhodopica 2: $100-116$.

Kilias A, Falalakis G, Mountrakis D. 1999. Cretaceous-Tertiary structures and kinematics of the Serbomacedonian metamorphic rocks and their relation to the exhumation of the Hellenic hinterland (Macedonia, Greece). International Journal of Earth Sciences 88: 513-531.

Kirchenbaur M, Pleuger J, Jahn-Awe S, Nagel TJ, Froitzheim N, Fonseca ROC, Münker C. 2012. Timing of high-pressure metamorphic events in the Bulgarian Rhodopes from Lu-Hf garnet geochronology. Contributions to Mineralogy and Petrology 163: 897-921.

Kotopouli CN, Pe-Piper G, Katagas CG. 1991. The metamorphism and migmatization of the Xanthe-Echinos metamorphic complex, Central Rhodope, Greece. Lithos 27: 79-93.

Krenn K, Bauer C, Proyer A, Klötzli U, Hoinkes G. 2010. Tectonometamorphic evolution of the Rhodope orogen. Tectonics 29: TC4001. DOI: 10.1029/2009TC002513.

Krohe A, Mposkos E. 2002. Multiple generations of extensional detachments in the Rhodope Mountains (northern Greece): evidence of episodic exhumation of high-pressure rocks. In: Blundell DJ, Neubauer F, von Quadt A, eds. The Timing and Location of Major Ore Deposits in an Evolving Orogen. Geological Society of London Special Publication 204: 151-178.

Kronberg P, Raith M. 1977. Tectonics and metamorphism of the Rhodope Crystalline Complex in Eastern Greek Macedonia and parts of Western Thrace. Neues Jahrbuch für Geologie und Paläontologie Monatshefte 11: 697-704.

Kydonakis K, Brun JP, Poujol M, Monié P, Chatzitheodoridis E. 2016. Inferences on the Mesozoic evolution of the North Aegean from the isotopic record of the Chalkidiki block. Tectonophysics 682: 65-84.

Le Fort P. 1996. Evolution of the Himalaya. In: Yin A, Harrison TM, eds. The Tectonic Evolution of Asia. Cambridge: Cambridge University Press, pp. 95-109.
Liati A. 1986. Regional metamorphism and overprinting contact metamorphism of the Rhodope Zone, near Xanthi (N. Greece). PhD dissertation, Univ. Carolo-Wilhelmina, Braunschweig, Germany.

Liati A. 2005. Identification of repeated Alpine (ultra) high-pressure metamorphic events by U-Pb SHRIMP geochronology and REE geochemistry of zircon: the Rhodope zone of Northern Greece. Contributions to Mineralogy and Petrology 150: 608-630.

Liati A, Gebauer D. 1999. Constraining the prograde and retrograde P-T-t path of Eocene HP rocks by SHRIMP dating of different zircon domains: inferred rates of heating, burial, cooling and exhumation for central Rhodope, northern Greece. Contributions to Mineralogy and Petrology 135: 340-354.

Liati A, Gebauer D, Fanning CM. 2011. Geochronology of the Alpine UHP Rhodope Zone: a review of isotopic ages and constraints on the geodynamic evolution. In: Dobrzhinetskaya LF, Faryad SW, Wallis S, Cuthbert S, eds. Ultrahigh-Pressure Metamorphism. Amsterdam: Elsevier, pp. 295-324.

Liati A, Theye T, Fanning CM, Gebauer D, Rayner N. 2016. Multiple subduction cycles in the Alpine orogeny, as recorded in single zircon crystals (Rhodope zone, Greece). Gondwana Research 29: 199-207.

Mancktelow NS. 1992. Neogene lateral extension during convergence in the Central Alps: evidence from interrelated faulting and backfolding around the Simplonpass (Switzerland). Tectonophysics 215: 295-317.

Marchev P, Georgiev S, Raicheva R, Peytcheva I, von Quadt A, Ovtcharova M, et al. 2013. Adakitic magmatism in post-collisional setting: an exemple from the Early-Middle Eocene magmatic belt in southern Bulgaria and northern Greece. Lithos 180-181: 159180.

Merle O, Cobbold PR, Schmid S. 1989. Tertiary kinematics in the Lepontine dome. In: Coward MP, Dietrich D, Park RG, eds. Alpine Tectonics. Geological Society of London Special Publication 45: 113-134.

Meyer W. 1968. Zur Altersstellung des Plutonismus im Südteil der Rila-Rhodope-Masse (Nordgriechenland). Geologica et Palaeontologica 2: 173-192.

Moulas E, Kostopoulos D, Connolly JAD, Burg JP. 2013. P-T estimates and timing of the sapphirine-bearing metamorphic overprint in kyanite eclogites from Central Rhodope, Northern Greece. Petrology 21: 507-521.

Mposkos E, Kostopoulos D. 2001. Diamond, former coesite and supersilicic garnet in metasedimentary rocks from the Greek Rhodope: a new ultrahigh-pressure metamorphic province established. Earth and Planetary Science Letters 192: 497-506.

Mposkos E, Chatzipanagis I, Papadopoulos P. 1998. New data on the boundary between the Pangaeon and Sidironero tectonic units in Western Rhodope. Bulletin of the Geological Society of Greece 32 (1): 13-21.

Mposkos E, Krohe A, Baziotis I. 2010. Alpine polyphase metamorphism in metapelites from Sidironero complex (Rhodope domain, NE Greece). In: Proceedings of the 19th Congress of the Carpathian-Balkan Geological Association, Thessaloniki, Greece, Special Volume of the Scientific Annals of the School of Geology of the Aristotle University of Thessaloniki, Vol. 100, pp. 173-181.

Nagel TJ, Schmidt S, Janak M, Froitzheim N, Jahn-Awe S, Georgiev N. 2011. The exposed base of a collapsing wegde: the Nestos Shear Zone (Rhodope Metamorphic Province, Greece). Tectonics 30: TC4009. DOI: 10.1029/2010TC002815.

Naydenov K, Peytcheva I, von Quadt A, Sarov S, Kolcheva K, Dimov D. 2013. The Maritsa strike-slip shear zone between Kostenets and Krichim towns, South Bulgaria - structural, petrographic and isotope geochronology study. Tectonophysics 595-596: 69-89. 
Papanikolaou D, Kranis H. 2004. Transect VII, sections 3.3 and 4.3: the Tethyan Area (Rhodope - Hellenides - Hellenic Arc and Trench - East Mediterranean Ridge). In: Cavazza W, Roure F, Spakman W, Stampfli GM, Ziegler PA, eds. The TRANSMED Atlas - The Mediterranean Region from Crust to Mantle (Part 2, CDRom). Berlin: Springer.

Papanikolaou D, Panagopoulos A. 1981. On the structural style of Southern Rhodope, Greece. Geologica Balcanica 11 (3): $13-22$.

Passchier CW. 2001. Flanking structures. Journal of Structural Geology 23: 951-962.

Patiño Douce AE, Harris N. 1998. Experimental constraints on Himalayan anatexis. Journal of Petrology 39: 689-710.

Petrik I, Janak M, Froitzheim N, Georgiev N, Yoshida K, Sasinkova $\mathrm{V}$, et al. 2016. Triassic to Early Jurassic (c. $200 \mathrm{Ma}$ ) UHP metamorphism in the Central Rhodopes: evidence from U-Pb-Th dating of monazite in diamond-bearing gneiss from Chepelare (Bulgaria). Journal of Metamorphic Geology 34: 265-291.

Pitra P, Ballèvre M, Ruffet G. 2010. Inverted metamorphic field gradient towards a Variscan suture zone (Champtoceaux Complex, Armorican Massif, France). Journal of Metamorphic Geology 28: 183-208.

Ricou LE, Burg JP, Godfriaux I, Ivanov Z. 1998. Rhodope and Vardar: the metamorphic and the olistostromic paired belts related to the Cretaceous subduction under Europe. Geodinamica Acta 11: 285309.

Rubatto D. 2002. Zircon trace element geochemistry: partitioning with garnet and the link between $\mathrm{U}-\mathrm{Pb}$ ages and metamorphism. Chemical Geology 184: 123-138.

Sawyer EW. 2000. Grain-scale and outcrop-scale distribution and movement of melt in a crystallising granite. Transactions of the Royal Society of Edinburgh: Earth Sciences 91: 73-85.

Sawyer EW. 2008. Atlas of migmatites. The Canadian Mineralogist Special Publication, 9. Ottawa, Canada: NRC Research Press.

Schenker FL, Burg JP, Kostopoulos D, Moulas E, Larionov A, von Quadt A. 2014. From Mesoproterozoic magmatism to collisional Cretaceous anatexis: Tectonomagmatic history of the Pelagonian Zone, Greece. Tectonics 33. DOI: 10.1002/2014TC003563.

Schmidt S, Nagel TJ, Froitzheim N. 2010. A new occurrence of microdiamond-bearing metamorphic rock, SW Rhodopes, Greece. European Journal of Mineralogy 22: 189-198.

Steck A, Hunziker J. 1994. The Tertiary structural and thermal evolution of the Central Alps - Compressional and extensional structures in an orogenic belt. Tectonophysics 238: 229-254.

Stevens G, Clemens JD, Droop GTR. 1997. Melt production during granulite-facies anatexis: experimental data from "primitive" metasedimentary protoliths. Contributions to Mineralogy and Petrology 128: 352-370.

Thompson AB. 1982. Dehydration melting of pelitic rocks and the generation of $\mathrm{H}_{2} 0$-undersaturated granitic liquids. American Journal of Science 282: 1567-1595.
Trouw RAJ, Passchier CW, Wiersma DJ. 2010. Atlas of mylonites and related microstructures. Berlin: Springer.

Turpaud P. 2006. Characterization of igneous terranes by zircon dating: implications for the UHP relicts occurrences and suture identification in the Central Rhodope, Northern Greece. PhD dissertation, Univ. Johannes Gutenberg, Mainz, Germany.

Turpaud P, Reischmann T. 2010. Characterization of igneous terranes by zircon dating: implications for UHP occurrences and suture identification in the Central Rhodope, northern Greece. International Journal of Earth Sciences 99: 567-591.

van Hinsbergen DJJ, Schmid SM. 2012. Map view restoration of Aegean-West Anatolian accretion and extension since the Eocene. Tectonics 31: TC5005. DOI: 10.1029/2012TC003132.

Vernon RH, Paterson SR. 2001. Axial-surface leucosomes in anatectic migmatites. Tectonophysics 335: 183-192.

Vielzeuf D, Montel JM. 1994. Partial melting of metagreywackes, Part 1: Fluid-absent experiments and phase relationships. Contributions to Mineralogy and Petrology 117: 375-393.

von Quadt A, Peytcheva I. 2005. The southern extension of the Srednogorie-type Upper Cretaceous magmatism in Rila-Western Rhodopes: constraints from isotope-geochronological and geochemical data. In: Proceedings of the Bulgarian Geological Society Annual Conference (80 ${ }^{\text {th }}$ Anniversary), Sofia, pp. 113-116.

Watson EB, Wark DA, Thomas JB. 2006. Crystallization thermometers for zircon and rutile. Contributions to Mineralogy and Petrology 151: 413-433.

Wawrzenitz N, Krohe A, Baziotis I, Mposkos E, Kylander-Clark ARC, Romer RL. 2015. LASS U-Th-Pb monazite and rutile geochronology of felsic high-pressure granulites (Rhodope, $\mathrm{N}$ Greece): effects of fluid, deformation and metamorphic reactions in local subsystems. Lithos 232: 266-285.

Weinberg RF, Mark G. 2008. Magma migration, folding, and disaggregation of migmatites in the Karakoram Shear Zone, Ladakh, NW India. Geological Society of America Bulletin 120: 994-1009.

White RW, Powell R, Holland TJB. 2001. Calculation of partial melting equilibria in the system $\mathrm{Na}_{2} \mathrm{O}-\mathrm{CaO}-\mathrm{K}_{2} \mathrm{O}-\mathrm{FeO}-\mathrm{MgO}-$ $\mathrm{Al}_{2} \mathrm{O}_{3}-\mathrm{SiO}_{2}-\mathrm{H}_{2} \mathrm{O}$ (NCKFMASH). Journal of Metamorphic Geology 19: 139-153.

Wyllie PJ. 1983. Experimental studies on biotite- and muscovitegranites and some crustal magmatic sources. In: Atherton MP, Gribble CD, eds. Migmatites, Melting and Metamorphism. Nantwich, UK: Shiva Publishing Limited, pp. 12-26.

Yanev Y, Innocenti F, Manetti P, Serri G. 1998. Upper EoceneOligocene collision-related volcanism in Eastern Rhodopes (Bulgaria) - Western Thrace (Greece): petrogenetic affinity and geodynamic significance. Acta Vulcanologica 10: 279-291.

Zachos S, Dimadis E. 1983. The geotectonic position of the SkalotiEchinos granite and its relationship to the metamorphic formations of Greek Western and Central Rhodope. Geologica Balcanica 13 (5): 17-24.

Cite this article as: Gautier P, Bosse V, Cherneva Z, Didier A, Gerdjikov I, Tiepolo M. 2017. Polycyclic alpine orogeny in the Rhodope metamorphic complex: the record in migmatites from the Nestos shear zone (N. Greece), Bull. Soc. géol. Fr. $188: 36$. 